\title{
Classical Asharāi Anthropology: Body, Life and Spirit
}

\author{
Ayman Shihadeh \\ School of Oriental and African Studies, University of London
}

lthough it is widely recognised that Asharism enters the sixth/twelfth century with
a physicalist theory of man and exits with an Avicennan-inspired body-soul
dualism, the exact nature and circumstances of this conversion, one of the starkest and most momentous shifts in school doctrine, remain little understood. ${ }^{1}$ In contrast to the considerable attention that al-Ghazâlī's theory of the soul, the earliest episode in the post-classical era, has received in recent scholarship, there are hitherto no focused studies on pre-Ghazālian classical Asharāi anthropology beyond a brief, but valuable, treatment of some of the school-founder's teachings. ${ }^{2}$ In relative terms, the interest that Mu'tazili anthropology has received is immense. ${ }^{3}$ Our immediate objective in the present article is to address this gap by offering a comprehensive exploration of the theory of man expounded in the available classical Asharā sources. A forthcoming study will then investigate the concerns and circumstances that were at play in the radical, but gradual, transformation that Asharī anthropology underwent during the late-fifth/eleventh and sixth/twelfth centuries, including criticisms of the philosophical theory of the rational soul.

\footnotetext{
${ }^{1}$ I would like to thank the editor of The Muslim World, Prof. Yahya Michot, for arranging the anonymous peer review of this article and for his comments.

${ }^{2}$ Daniel Gimaret, La doctrine d'al-Ash'arī (Paris: Cerf, 1990), based largely on Ibn Fūrak's conspectus of al-Asháarī's theology, Mujarrad maqālāt al-Ashiarī. Exact page references are given below.

${ }^{3}$ For instance: Josef van Ess, Theologie und Gesellschaft im 2. und 3. Jahrbundert Hidschra, 6 vols. (Berlin and New York: Walter de Gruyter, 1991-1995), passim; Wilferd Madelung, "Ibn al-Malāhịimī on the Human Soul," The Muslim World 102.3 (2012): 426-32; Margaretha Heemskerk, "Abd al-Jabbār al-Hamadhānī on Body, Soul and Resurrection," in A Common Rationality: Muitazilism in Islam and Judaism, eds. C. Adang and S. Schmidtke (Würzburg: Ergon, 2007), 127-56; Sophia Vasalou, "Subject and Body in Mutazilism, or: Mutazilite Kalām and the Fear of Triviality," Arabic Sciences and Philosophy 17 (2007): 267-98; Richard Frank, Beings and their Attributes (Albany, NY: State University of New York Press, 1978), 39-52; Majid Fakhry, "The Mutazilite View of Man," in Recherches d'islamologie: Recueil d'articles offert à Georges C. Anawati et Louis Gardet par leurs collègues et amis (Leuven: Peeters, 1977), 107-21; J. Peters, God's Created Speech (Leiden and Boston: E.J. Brill, 1976), 159 ff.; 'Abd al-Karīm 'Uthmān, Naz̧ariyyat al-taklīf: ārā' 'Abd al-Jabbār al-kalāmiyya (Beirut: Mu'assasat al-Risāla, 1971), 305 ff.; Isma'il al-Fārūqī, "The Self in Mutazila Thought," International Philosophical Quarterly 6 (1966): 366-88.

(C) 2012 Hartford Seminary.

Published by Blackwell Publishing Ltd., 9600 Garsington Road, Oxford, OX4 2DQ, UK and 350 Main Street, Malden, MA 02148 USA.

DOI: $10.1111 /$ j.1478-1913.2012.01409.x
} 
The present study will explore the ontological structure of man, particularly the basic and interrelated elements of body, the attribute of life, and spirit. Our scope thus excludes the detailed dissection of the properties and workings of the further attributes that characterise man, including knowledge, perception, will and capacity, some of which are treated elsewhere, for instance in studies on kalām epistemology, theories of action and doctrines of divine attributes. Nor do we intend to cover any eschatological discussions, including the inquisition in the grave, except where they shed light on human ontology in this world.

By "classical Asharism", I refer to the earlier phase that drew mainly on Bașran Mutazilism and Traditionalist theology, in contrast to neo-Asharism, which took its cue chiefly from classical Asharism and Avicennan philosophy. Classical Asháāis thus include, first of all, members of the school who lived in the fourth/tenth century and the first three quarters of the fifth/eleventh century, including al-Asharī (d. 324/936), al-Bāqillānī (d. 403/1013), Ibn Fūrak (d. 406/1015), 'Abd al-Qāhir al-Baghdādī (d. 429/1038), al-Qushayrī (d. 465/1072), al-Juwaynī (d. 478/1085) and al-Fūrakī (d. 478/1085). ${ }^{4}$ In post-Juwaynian Ashárism, al-Ghazālī (d. 505/1111) marks the beginning of the transformation that culminates eventually in the rise of neo-Asharism, which is given its definitive formulation in the thought of al-Rāzī (d. 606/1210). ${ }^{5}$ However, the classical Asharāi tradition continues, largely unaffected by al-Ghazālī, until the third quarter of the sixth/twelfth century, and is represented by several extant sources. ${ }^{6}$ These include: the works of two of al-Juwaynī's most important students of kalām, Abū l-Qāsim al-Anșārī (d. 512/1118) and al-Kiyā al-Harrāsī (d. 504/1110); a recently-discovered summa by al-Anșārī's student and Fakhr al-Dīn al-Rāzī's father Dịā’’ al-Dīn al-Makkī (d. $559 / 1163-64) ;^{8}$ what appears to be the earliest kalām work by al-Rāzī, which is based

\footnotetext{
${ }^{4}$ We shall concentrate here on the mutakallimūn of the school, generally considered the chief representatives of Asharism, to the exclusion of more traditionalist figures such as al-Khațābī (d. 388/998) and al-Bayhaqī (d. 458/1066).

${ }^{5}$ See: Ayman Shihadeh, "From al-Ghazālī to al-Rāzī: 6th/12th Century Developments in Muslim Philosophical Theology," Arabic Sciences and Philosophy 15.1 (2005): 141-79; and idem., "Ibn Ghaylān al-Balkhī's Criticism of the Materia Medica of Avicenna's Canon of Medicine: An Episode of Post-Ghazālian Proto-Neo-Ashárism" (forthcoming). The designations "classical" and "neo-Asharism" correspond roughly to Ibn Khaldūn's "earlier" (al-aqdamūn) and "later" Ashárīs (al-muta'akhkhirūn) (al-Muqaddima, ed. 'A. al-Shaddādī, 5 vols. [Casablanca: Bayt al-Funūn wa-l-Ulūm wa-l-Ādāb, 2005], 3, 33-6).

${ }^{6}$ I discuss the development of late-fifth/eleventh- and sixth/twelfth-century, post-Juwaynian Asharism in more detail in a forthcoming publication.

${ }^{7}$ Al-Anșārī, al-Ghunya fì l-kalām, MS Istanbul, Topkapı Sarayı Müzesi Kütüphanesi, Ahmet III, 1916; idem., Sharḅ al-Irshād, MS Princeton, University Library, Yahuda, 634 (an incomplete copy that does not include the section on the spirit); Sharb al-Irshād, MS Istanbul, Süleymaniye Kütüphanesi, Aya Sofia, 1205 (facsimile edition: intro. Hasan Ansari and Sabine Schmidtke [Berlin: Free University of Berlin; Tehran: Mīrāth-i Maktūb, 2012]; I am grateful to Dr Ansari for supplying me with a copy of the section on the spirit); al-Kiyā al-Harrāsī, Ușūl al-dīn, MS Cairo, Dār al-Kutub al-Mișriyya, 290 Kalām. ${ }^{8}$ MS Hyderabad, Andhra Pradesh Oriental Manuscript Library, Kalām 13 (previously housed at the Āṣafiyya Library); published as Fakhr al-Dīn al-Rāzī's Father, Diyāi al-Dīn al-Makkī, Nihāyat 
closely on al-Juwaynī's Irshād and Shämil and perfectly representative of classical Ash'arī theology;' and an early commentary on al-Juwaynī's Irshäd by the Andalusian al-Fazārī (d. Granada, 552/1157 or slightly later), which contains much material from earlier Ashárī sources, including al-Bāqillānī's Hidāya, and is used here for the first time. ${ }^{10}$ Al-Rāzī's other extant works exhibit greater engagement with philosophical theories and are hence unrepresentative of classical Asharism. Using these first-hand, classical Ash'arī sources, it has been possible to construct a fairly detailed account of the theories propounded by their authors.

\section{The Sources}

The neglect of classical Asharī anthropology in contemporary scholarship is due partly to the dearth of relevant material in the published primary sources. That the subject, nevertheless, was afforded much attention in classical Asharism is attested both by the fact that leading school figures, as we shall see, devoted entire works to the subject and in the substantial, including dedicated, discussions found in several extant manuscript texts. These discussions fall under the following four categories.

First, man (insān) is considered qua composite body (jism, jumla) in discussions on general ontology, which appear in the lengthier summae, exemplified by al-Juwaynī's Shämil, particularly in various places in discussions on atoms, accidents and causes (sg. 'illa). Second, qua living being (hayy) predicated of various attributes associated with living beings, man is central to treatments of divine attributes, which are analogised to their human cognates. Of paramount relevance here are discussions on the properties $(a b \underline{k} \bar{a} m)$ of the attribute of life ( $h a y a \bar{a}$ ), best illustrated in the lengthy chapter devoted to this subject in al-Baghdādī's Tafsīr asmä Allāh. ${ }^{11}$

Third, aside from these physical and metaphysical discussions, treatments of the "reality of man" (ḅaqiqat al-insān) can be found in the more extensive summae. Focusing specifically on the ontology of man, these investigate the relation between the human body and the attributes that define the obligated agent (al-mukallaf). The following are the sources known to contain dedicated discussions, including non-extant ones:

al-marām fì dirāyat al-kalām: Facsimile of the Autograph Manuscript of Vol. II, intro. Ayman Shihadeh (Berlin: Free University of Berlin; Tehran: Mīrāth-i Maktūb, 2012). On the author, see the introduction. The Nihāya is based closely on al-Anșārī's Ghunya.

${ }^{9}$ Fakhr al-Dīn al-Rāzì, Ușūl al-dīn, MS Beirut, American University of Beirut Library, 297:R27kA. On this text, see: Ayman Shihadeh, "Al-Rāzī's Earliest Kalām Work," forthcoming in Theological Rationalism in Medieval Islam: New Sources and Perspectives, ed. G. Schwarb and L. Muehlethaler (Peeters: Leuven, 2012). The work was previously cited in: idem., The Teleological Ethics of Fakhral-Dìn al-Rāzì (Leiden and Boston: E.J. Brill, 2006), 7.

10 'Alī ibn Muhammad al-Fazārī, Manhaj al-sadād fì sharḥ al-Irshād, MS London, British Library, OR. 9645. On this source, see the Appendix at the end of this article.

11 'Abd al-Qāhir al-Baghdādī, Tafsīr asmā’ Allāh al-ḥusnā, MS London, British Library, OR. 7547, f. 121b ff.

(c) 2012 Hartford Seminary. 
1. Ibn Fūrak's conspectus of al-Asharī's teachings, the Mujarrad (pp. 215-18). ${ }^{12}$

2. Al-Bāqillānī's Kitāb al-Insān, cited by al-Anșārī. Considering the manner in which the latter refers to the title, this appears to be a dedicated book, rather than a part of a larger work. The first chapter is reportedly entitled, "On the properties of life, the characterisation of the obligated agent, what he is, and related matters" (al-qawl fi aḅkām al-ḥayāt wa-șifat al-mukallaf wa-man huwa wa-mā yattașilu bi-dhālika). ${ }^{13}$

3. Al-Bāqillān̄̄'s major theological summa Hidāyat al-mustarshidīn reportedly contained a chapter, now lost, on the "obligated agent" (Kitāb al-mukallaf), in which the author discusses the reality of man "at length". ${ }^{14}$

4. Al-Juwaynī refers several times in the Shāmil to a chapter either on man and spirit ( $b \bar{a} b$ al-insān wa-l-rūḥ wa-mainā-bumā), or on man (kitāb or bāb al-insān), which would have been located in the second half of the book, now lost. ${ }^{15}$ In the beginning of the part on "justice and injustice" (al-taidìl wa-l-tajwìr) in the extant abridgement of the Shämil, he lists several topics that, it seems, he intends to treat in that part, including mána al-insān wa-l-rūth wa-l-nafs. ${ }^{16}$ However, there is no trace of this chapter in the abridgement; and al-Fazārī confirms that despite these internal references, no such chapter was actually included in the Shämil. ${ }^{17}$ So either the chapter was never written, or it was written but somehow failed to be transmitted.

5. Al-Anșārī, Ghunya (ff. 154a-156b).

6. Al-Makkī, Nihāyat al-marām (ff. 84a-87b).

7. Al-Fazārī, Sharḥ al-Irshād (ff. 103a-104b). The section on the spirit is appended with a discussion on man, which has no counterpart in the Irshād.

Fourth, several discussions of the spirit (al-rūh) are also found in both medium-sized and long summae, which in most cases are concerned primarily with eschatology. The following dedicated discussions are known:

${ }^{12}$ Ibn Fūrak, Mujarrad maqālāt al-Shaykh Abī l-Hasan al-Ashiarī, ed. D. Gimaret (Beirut: Dār al-Mashriq, 1987).

${ }^{13}$ Cited in al-Anșārī, Ghunya, f. 154a; cf. al-Makkī, Nihāya, f. 84a. I have not found any further references to this work. It is not mentioned by al-Qādī Tyāḍ (Tartīb al-madārik wa-taqrīb al-masālik, eds. S. A. Árāb et al., 8 vols. [Rabat: Wizārat al-Awqāf wa-l-Shưūn al-Islāmiyya, 1981-1983], 7, 69-70). Earlier works dedicated to man — evidence of an established theological genre — are attributed to Abū 1-Hudhayl, al-Naẓzām, Abū 'Alī al-Jubbāìi, Abū Hāshim al-Jubbāìi, Abū Sahl al-Nawbakhtī and Abū Muḥammad al-Nawbakhtī (see Gregor Schwarb, Handbook of Mu'tazilite Authors, Works and Manuscripts [Leiden and Boston: E.J. Brill, forthcoming in 2013 or 2014]; I thank Dr Schwarb for these details).

${ }^{14}$ Al-Fazārī, Sharḥ al-Irshād, f. 103a (margin). On the extant fragments of the Hidāya, see Sabine Schmidtke, "Early Ashárite Theology: Abū Bakr al-Bāqillān̄̄ (d. 403/1013) and his Hidāyat al-mustarshidinn," Bulletin d'Études Orientales 60 (2011): 39-71; Daniel Gimaret, "Un extrait de la Hidāya d'Abū Bakr al-Bāqillānī: Le Kitāb at-tawallud, réfutation de la thèse mu tazilite de la génération des actes," Bulletin d'Études Orientales 58 (2009): 259-313.

${ }^{15}$ Al-Juwaynī, al-Shāmil fì uṣūl al-dìn, eds. 'A. al-Nashshār et al. (Alexandria: Munsha'at al-Maārif, 1969), 668; 669; idem. (abridgement by a certain Ibn al-Amīr), al-Kāmil fī ikhtișār al-Shāmil, MS Istanbul, Topkapı Sarayı Müzesi Kütüphanesi, Ahmet III, 1322, ff. 125b; 126a; 137a. The latter text was recently published in a very poor edition, which will not be cited here (ed. J. Abd al-Munim, 2 vols. [Cairo: Dār al-Salām, 2010]).

${ }^{16}$ Al-Juwaynī (Ibn al-Amīr), Ikhtiṣār, f. 224b.

${ }^{17}$ Al-Fazārī, Sharḥ al-Irshād, f. 103a. 
1. Ibn Fūrak, Mujarrad, on the spirit and life (p. 257).

2. Al-Bāqillānī's Hidāya reportedly included a chapter on the spirit, now lost. ${ }^{18}$

3. Al-Qushayrī, Risāla (vol. 1, p. 205). ${ }^{19}$ The discussion on the spirit is guided by Sufi concerns, but contains unmistakable Asháāī elements.

4. Al-Juwaynī, Kitāb al-Nafs. No copies are known of this major dedicated work, which, according to the author, was approximately one thousand folios long. ${ }^{20}$

5. Al-Juwaynī $\operatorname{Irshād~(p.~377).21~}$

6. Al-Mutawallī, Mughnī (p. 57). ${ }^{22}$

7. Al-Anșārī, Ghunya (ff. 217a-218a).

8. Al-Harrāsī, Ușūl al-dìn (ff. 247b-248b).

9. Al-Makkī, Nihāyat al-marām (ff. 87b-90a).

10. Al-Fazārī, Sharḥ al-Irshād (ff. 101b-103a).

11. Al-Rāzì, Ușūl al-dìn (ff. 178b-180a).

Recognising the close thematic affinity between discussions of man and spirit, some sources treat them in adjoining sections. This can be seen in al-Makkī's Nihäyat al-marām and al-Fazārī's Sharḥ al-Irshād, as well as al-Juwaynī's planned chapter on "man and spirit" in the Shämil. As we shall see in the present article, though the discussions may be juxtaposed, the extant sources never advance a fully coherent and integrated theory.

\section{The Definition of "Man" (al-insān)}

Like the Bașran Mutazila, classical Asharīs propounded an ontology that conceived of the created world (al-älam), defined as everything other than God, as consisting of two primary types of entities: substances (jawāhir, sg. jawhar) and accidents ( $a^{\prime} r \bar{a} d$, sg. (arad). A substance is an indivisible, space-occupying atom ( $j u z$ ') that is amenable to receiving accidents, whereas an accident, for Ash'arīs, is an entity that inheres in an atom and constitutes an attribute (sifa) for it. ${ }^{23}$ An individual atom or accident is said to be a

\footnotetext{
${ }^{18}$ Cited in al-Fazārī, Sharh al-Irshād, f. 102b (margin).

19 'Abd al-Karīm al-Qushayrī, al-Risālat al-Qushayriyya, ed. 'A. Maḥmūd and M. al-Sharīf, 2 vols. (Cairo: Dār al-Kutub al-Hadītha, 1972).

${ }^{20}$ Al-Juwayn̄̄, al-'Aqīdat al-Niz̄āmiyya, ed. M. al-Zubaydī (Beirut: Dār Sabīl al-Rashād and Dār al-Nafā'is, 2003), 247 [the best critical edition of this work]; cf. al-Fazārī, Sharḥ al-Irshād, ff. 101b (margin); 102b.

${ }^{21}$ Abū l-Ma'ālī al-Juwaynī, Kitāb al-Irshād, ed. M. Mūsā and 'A. 'Abd al-Hamīd (Cairo: Maktabat al-Khānjī, 1950).

${ }^{22}$ Al-Mutawallī, al-Mughnī, ed. M. Bernand, Supplément aux Annales islamologiques 11 (1986).

${ }^{23}$ Al-Juwaynī, Shāmil, 142-3; 165; 167-8. On Ashárī atomism, see Abdelhamid Sabra, "Kalām Atomism as an Alternative Philosophy to Hellenizing Falsafa," in Arabic Theology, Arabic Philosophy. From the Many to the One: Essays in Celebration of Richard M. Frank, ed. J. Montgomery (Leuven: Peeters, 2006), 199-272; Richard M. Frank, "The Aš‘arite Ontology: I Primary Entities," Arabic Sciences and Philosophy 9 (1999): 163-231; idem., "Bodies and Atoms: The Ash'arite Analysis," in Islamic Theology and Philosophy: Studies in Honor of George F. Hourani, ed. M. Marmura (New York: State University of New York Press, 1984), 39-53 and 287-293.
} 
"thing" (shay'), or an "entity" ( $d h \bar{a} t)$, a term whose referent must both exist and, strictly speaking, be one (wāhid) and indivisible: a monad. ${ }^{24}$

A body (jism) is an aggregate, a composite (jumla), of atoms that adhere to each other by means of the accident of composition ( $\left.t a^{\prime} l i f\right)$, an instance of which inheres in each atom in the body. Hence, a body, properly speaking, is not a single entity, but a multiplicity of things. The arrangement of the atoms determines the structure (binya or bunya), both internal and external, of the body, while the accidents that inhere in its atoms determine its other attributes, for instance, colour, smell and temperature. An object such as a tree, accordingly, will be a composite of numerous atoms conjoined to form a particular structure, each possessed of a range of accidents, such that some parts are green and moist, and others brown and dry. Yet it will not have an essence of "treeness" that would make it a unified entity. Al-Baghdādī hence writes in the section on the "forming (tașwir r) of animate beings" that it is God "who forms (yușawwir) the foetus in the womb, without assistance from any other being, and without a nature $\left(t a b \bar{\imath}^{\prime} a\right)$ that causes $(t \bar{u} j i b)$ that form in the foetus". ${ }^{25}$

In the absence of a unifying essence, no composite body could have a realdefinition in the Aristotelian sense, which would delineate what a thing is in terms of its genus and differentia, and thereby how it relates to other beings. Bodily objects can only be given nominal definitions, which are intended to discriminate (tamyiz) them from other beings.

This discrimination is achieved by the definition of "man", different versions of which are transmitted in the extant sources. The earliest is attributed to al-Ash'arī, who reportedly held that the referent ( $\left.m a{ }^{\prime} n \bar{a}\right)$ and definition ( hadd) of "man" is "this visible body that is composed in this manner of composition and structured in this type of specific structure" ( $h \bar{a} d h \bar{a}$ l-jasad al-zāhhir al-murakkab bi-hādhā l-tarkīb al-mabnī bi-hädhā l-darb min al-binyat al-makhșūșa). "Man", hence, refers to "this composite" ( $h \bar{a}$ dhibi l-jumla), with which we are familiar, just as "palm" refers to a tree that has the familiar tree form ( byy $^{\prime}$ ) ) particular to it. ${ }^{26}$ This definition is borrowed from the Bașran Mutazila and can be traced back to Abū 1-Hudhayl al-Allāf (d. between 226/840 and 236/850). ${ }^{27}$ Classical Asharīs often acknowledge that they share it with the "majority" $(a l-d a h m \bar{a})$ of the Mutazila. ${ }^{28}$

${ }^{24}$ For instance: al-Baghdādī, Ușūl al-dīn (Istanbul: Madrasat al-Ilāhiyyāt bi-Dār al-Funūn al-Turkiyya, 1928), 35; al-Juwaynī, Shāmil, 124 ff.; 346-7; cf. Frank, "The Aš‘arite Ontology," 164-77, esp. 169. Al-Bāqillānī (al-Inșāffì-mā yajibu i tiqāadu-hu wa-lā yajūzu al-jahl bi-hi, ed. M. Z. al-Kawtharī [Cairo: Mu'assasat al-Khānjīi, 1963], 31) writes that "composition ( $t a^{\prime} l i \bar{f}$ ) can only involve two or more things (shay ayn)", that is, two or more simple entities. On the definition of "one", see Gimaret, Les noms divins en Islam (Paris: Cerf, 1988), $191 \mathrm{ff}$.

${ }^{25}$ Al-Baghdādī, Asmā̀, f. $234 \mathrm{a}$.

${ }^{26}$ Ibn Fūrak, Mujarrad, 215.

${ }^{27}$ For instance: al-Asháāī, Maqālāt al-Islāmiyyīn wa-ikhtilāf al-muṣallīn, ed. H. Ritter (Wiesbaden: Franz Steiner, 1980), 329; van Ess, Theologie und Gesellschaft, 3, 245-6; Heemskerk, "Abd al-Jabbār," $129 \mathrm{ff}$.

${ }^{28}$ Al-Anșārī, Ghunya, f. 155b; cf. Ibn Fūrak, Mujarrad, 215; al-Fazārī, Sharḥ al-Irshād, f. $103 a$. 
A slightly different version of the same definition is given by al-Harrāsī, who writes that "man" is "this erect structure ( $h \bar{a} d h \bar{a} l$-haykal al-qä im) that we observe, [which consists] of body and accidents". ${ }^{29}$ For al-Anșārī, the "reality (baqiqa) of man" is "this composite (jumla) that consists of multiple parts (dhāt al-ab'ād)", and adds:

If we are asked, "What is your definition of 'man'?", we say: ["Man" is] that which has this specific structure by which he is distinct from the structures of cattle, horses, palm trees and the like. Every man has this form (șüra) and structure; and all that has this form and structure is a man..$^{30}$

Paraphrasing al-Anșārī, his student al-Makkī explains that the definition employs self-evident concepts:

If it is said, "What is your definition of 'man'?", we say: [Man is] that which has the specific external and internal structure (al-binyat al-makhșüșa zähiran wa-bätinan) by which he is distinct from the structures of cattle, palm trees and the like. This is a sensible object (amr maḥsūs). Sensible and visible objects are patently evident (al-maḥsūsāt al-mushāhadāt wädihhāt); and it is futile to seek to make evident what is already patently evident $!^{31}$

In other words, since the referent of "this specific structure" is known by means of sensory, particularly visual perception, which consequently gives rise to an item of immediate knowledge ('ilm darürî), it would be pointless, for the purposes of the definition, to attempt to explicate the meaning of this phrase in any detail, for instance, by providing a descriptive account of human anatomy. ${ }^{32}$ We shall return shortly to the significance of al-Makkī's reference to "external and internal structure".

That this definition of "man" effects the discrimination of the object defined from all other objects is emphasised by al-Fazārī, who confirms that the definition was held unanimously by all Asháāis:

What all our school authorities are unanimous on, both the earlier and later ones, is that "man" is this Ädamic figure (shakbș) that has this structure by which it is differentiated from everything else. Hence, our saying "man" effects a distinction (tamayyuz) between it and all other classes of animate beings (ḥayawānāt), including angels, jinn and the like. They say the same concerning all other classes of animate beings: so "elephant" is that being that has the structure familiar [to us], and the same goes for horses. ${ }^{33}$

Nonetheless, although the definition is presented as effectively differentiating man from other bodily objects, especially plants and animate beings, this is not the chief task it is

${ }^{29}$ Al-Harrāsī, Ușūl, f. 248b.

${ }^{30}$ Al-Anșārī, Ghunya, ff. 155b; 156a.

${ }^{31}$ Al-Makkī, Nihāya, f. 87b.

32 On sensory knowledge being a sub-division of immediate knowledge, see, for instance, al-Baghdādī, Ușül, 8-9.

${ }_{33}$ Al-Fazārī, Sharh al-Irshād, f. 103a. 
intended to serve, but in fact merely a condition that the definition is expected to satisfy. For the principal objective of the definition, evident from the discussions in which it is set out and invoked, is not to explain how man fits within a general cosmological and zoological framework, but instead to circumscribe the concept "man" set against the backdrop of a number of other competing configurations proposed in earlier kalām works, which are either narrower (for instance, that it includes only some atoms located in the heart), or broader (for instance, that it includes the combination of body and soul). ${ }^{34}$ The objective that this demarcation of the concept's boundaries served was to define the subject of obligation (mukallaf), which revelation addresses and about which it makes numerous statements: is it the whole body, something within the body, something without the body, or some combination of bodily and non-bodily components?

To ascertain the definition of "man", theologians appealed to the sense in which the expression is normally used by the speakers of the language, particularly the pre-Islamic Arabic that the Qur'ān uses, for which the expert and well-informed opinions of the lexicographers ( $a b l$ al-lugha) are frequently cited as corroborating evidence. According to al-Asharīi, when asked, "What is man?", lexicographers simply point (ashāra) to the body. ${ }^{35}$ Al-Anșārī writes:

The majority of the lexicographers accept [our foregoing definition of man]. It is furthermore attested by unambiguous occurrences (nușūs) in the Qur'ān and by the consensus of scholars. The Arabs' assertion in reference (ishära) to the visible body, "This is a man" - considering both the widely-known fact that they did so and our knowledge of their intended [referent] — is equivalent to their assertion with respect to "horse", "house" and "palm tree", "This is a palm tree", "This is a horse", and "This is a mosque" [sic.]. The [Muslim] community, before the time of al-Naz̧ām and Mu'ammar, was unanimous on that man is perceptible to the eye. God, exalted, says, "We created man of a sperm-drop, a mingling, to test him" [Q. 76.2]. ${ }^{36}$

He then cites further Qur'ānic evidence attesting to the definition of "man" as the whole bodily composite $(23.12-13 ; 15.26 ; 82.6 ; 80.17-21)$. Al-Fazārī justifies the appeal to traditional and lexical evidence, to the exclusion of rational evidence in defining "man":

The evidence for what we and all our school authorities have maintained is that reason has no access to [the referents of] names (tasmiyāt); for these can only be gleaned from lexicon (lugha) and revelation (shar). Accordingly, since the Arabs never use the expression "man" for one part of [the human body], its senses, its life, its soul, nor any of these [sic.], but assigned (awqafa) it to this composite that we

\footnotetext{
${ }^{34}$ On competing conceptions of man advanced in earlier Mutazilism, particularly by Muammar ibn 'Abbād (d. 215/830) and al-Nažz̄ām (d. 230/845), see: van Ess, Theologie und Gesellschaft, 3, 83 ff.; 3 , 369 ff.; 4, 513 ff.; Hans Daiber, Das theologisch-philosophische. System des Muiammar ibn 'Abbād as-Sulamī (Beirut: Franz Steiner, 1975), 339-411.

${ }^{35}$ Ibn Fūrak, Mujarrad, 215.

${ }^{36}$ Al-Anșārī, Ghunya, f. 156a.
} 
can point to (mushār ilay-hā), if an Arab says, "I saw", or "I met", or "I spoke with a man (insān)", he will be referring to this visible composite. ${ }^{37}$

He too then cites representative Qur'ānic evidence $(80.17 ; 84.7 ; 23.12)$ before arguing that "man" denotes the bodily composite in a literal sense (baqiqa), rather than figuratively (tajawwuzan), as supporters of competing definitions would claim. For had the expression had a different literal meaning, this surely would have been acknowledged by the lexicographers and attested in reports of authentic usage among the Arabs. $^{38}$

The reasoning that underlies the evidence adduced is this. "Man" in ordinary Arabic denotes the body. God, the Lawgiver, is entitled to redefine this expression for the purposes of His revealed religion, as He does with numerous other expressions. More specifically, in the theological voluntarism of classical-Asharism, God is even entitled to redefine expressions that have ethical, soteriological and eschatological implications, such as "man". If He were to redefine an expression, it would retain its lexical (lughawi) sense or senses and would acquire a new, "religious" ( shar $\vec{i}$ ) sense. In other cases, even when an expression is not redefined by God, the theologian may argue that an expression ought to be redefined on rational grounds, in which case the lexical sense may be deemed "figurative" (majāz) and the new sense "literal" (haqiqqa), or vice versa. ${ }^{39}$ Yet in the case of "man", the expression, it is argued, is not redefined by God, but continues to be employed in its standard lexical sense, as various Qur'ānic verses attest. Nor can the mind arrive at its own definition of "man" that either confirms, or diverges from, the lexical sense, for instance by discerning an intrinsic essence of man. Therefore, the theological sense of "man", in classical Asharism, is identical with its lexical sense.

Now, the definition of "man" by reference to the familiar form of the human body succeeds in differentiating the object defined from all other bodily objects. A taxonomy of these is provided by al-Baghdādī, who explains that bodies (sg. jism) are divided into those that grow and those that do not grow. The former are subdivided into plants and animate beings ( hayawān), which are further subdivided into those that are sensible to us and those that are normally insensible to us, but which may become sensible in the hereafter or in exceptional situations. The latter subdivision, that of insensible animate beings, includes four classes (jins): angels, houris, jinn and demons. ${ }^{40}$ The former subdivision, that of sensible animate beings, too includes four classes: animals that walk on legs, animals that fly (e.g. carnivorous and herbivorous birds, and flying insects), animals that swim, and animals that crawl (e.g. snakes, scorpions, worms and crawling

${ }^{37}$ Al-Fazārī, Sharh al-Irshād, f. 103b.

${ }^{38}$ Al-Fazārī, Sharḥ al-Irshād, ff. 103b-104a.

39 An example is the expression "living" ( hayy), to be discussed below, p. $449 \mathrm{ff}$.

${ }^{40}$ Al-Baghdādī, Ușūl, 38-9; cf. idem, al-Farq bayna l-firaq, ed. M. Badr (Cairo: Maṭbaáat al-Maārif, 1910), 316. In $A s m \vec{a}$ (ff. 123a-b), he divides insensible animate beings ( $a b y \cdot \vec{a}$ ) (here, not a subclass of bodies) into two types. The first is God, who is unique in being an animate being that never dies or changes. The second includes three classes: angels, jinn and demons. 
insects). Animals that walk are further divided into human beings, herbivorous ( $b a h \bar{a}^{\prime} i m$ ) and carnivorous ( $s i b \bar{a}$ ) animals that walk, and insects that walk. Al-Baghdādī considers the humanoid Gog and Magog ( $\left.Y a^{\prime} j \bar{u} j w a-M a^{\prime} j \bar{u} j\right)$ human, but mentions others who consider these creatures $b a h \vec{a}$ im, and as such religiously permissible to consume. ${ }^{41}$ Note that the primary fourfold division of sensible animals according to their manner of mobility is Qur'ānically-inspired (cf. 24.45; 6.38), and appeals to external parts and structural features of animal bodies, for instance wings in the case of flying animals. This forces the author to exclude certain winged creatures from being classed as flying animals: namely, flying beetles (classed as walking animals), angels (cf. Q. 35.1), and the Prophet's cousin Ja'far al-Tayyār. ${ }^{42}$ Al-Baghdādī offers this taxonomy as an alternative to that of the philosophers. ${ }^{43}$ Aristotle, by contrast, groups animals into genera and species according to more physiological criteria. ${ }^{44}$

Nonetheless, as the Mutazila had realised, there are complications that suggest that, being based on the mere superficial appearance of the object defined, the definition neither applies to all human beings nor adequately excludes all these other classes of beings, just mentioned. For it can be objected that conceiving of "man" as "this familiar form" (al-șürat al-ma'hūda) implies that when a non-human living being, particularly an angel or a jinn, takes human shape, it would be properly human, rather than an angel or a jinn in disguise, and that a stone or wooden sculpture of a man would be literally a man. ${ }^{45}$ The foremost examples of this are the cases of Gabriel who is said to have visited the Prophet in the shape of a companion, Dihya al-Kalbī, and the angel who appeared to Mary "in the shape of a perfect man" ( fa-tamaththala la-hä basharan sawiyyan, Q. 19.17). Likewise, the humans whom, according to the Qur'ān, God transforms into pigs and apes would completely cease to be human (2.65; 7.166).

Al-Anșāî transmits two contrasting positions upheld by his fellow Ashárīs concerning this problem. The majority define "man" as the being that has this familiar external form (al-șürat al-zāahira), in which case an anthropomorphic angel or wooden sculpture

\footnotetext{
${ }^{41}$ On Gog and Magog, see: Emeri van Donzel and Andrea Schmidt, Gog and Magog in Early Syriac and Islamic Sources (Leiden and Boston: E.J. Brill, 2009), 65 ff.; 88 ff.; "Ya'djūdj wa-Ma'djūdj," EI2; "Gog and Magog," Encyclopaedia of the Qur'ān.

42 "Flying Jafar", or "Two-winged Jaffar" (dhū l-janāḥayn), on whom, see "Djaffar b. Abī Ṭālib," EI2.

${ }^{43}$ Al-Baghdādī, Ușūl, 38-9; idem., Asmā̄, ff. 123a-b; cf. idem., Farq, 316.

${ }^{44}$ On this, see: Pierre Pellegrin, La classification des animaux chez Aristote: Statut de la biologie et unité de l'aristotélisme (Paris: Les Belles Lettres, 1982).

${ }^{45}$ Al-Anșārī, Ghunya, f. 156b; cf. al-Fazārī, Sharh al-Irshād, f. 104a. To illustrate the manner in which the angel's transformation was understood, we could consider al-Juwaynī's response to the following query sent to him by 'Abd al-Haqq al-Ṣiqillī (d. Alexandria, 466/1073), whom he met in Mecca in 450/1058 (Ajwibat Imām al-Haramayn al-Juwaynì an as' ilat al-Imām 'Abd al-Haqq al-Siqillī, ed. J. 'A. al-Jihānī [Amman: Dār al-Rāzī, 2007], 60-3). According to some hadīths, the size of Gabriel's body is huge; so when he appears to the Prophet in human form (tamaththul), are the surplus atoms of his body left behind in another place, or are they annihilated by God? Al-Juwaynī accepts both possibilities, but favours the latter. He rejects that Gabriel retains his shape but appears as a man only in the Prophet's imagination (takhyil), possibly a reference to Avicenna's theory of prophecy.
} 
are each properly said to be "a man". This indeed is the earliest school doctrine advocated by al-Asharīi who, according to Ibn Fūrak, maintained that humans transformed into pigs and apes are no longer human and that an anthropomorphic Gabriel is human. ${ }^{46}$ The other school position defines "man" as the being that has "this external and internal form and structure" ( hädhihi l-șüra wa-l-binyat al-zāhira wa-l-bātina). Accordingly, anthropomorphic angels, wooden sculptures and other simulacra would be non-human; "for man contains a heart, life, senses, a chest cavity, bones, ribs, a liver, and all the organs involved in nutrition, while the sculpture has none of that". ${ }^{47}$ This, as we have seen, is the position favoured by al-Makkī, and is also defended much earlier by al-Kalābādhī (d. 380/990 or later). ${ }^{48}$

\section{The Animate Being's Attributes (șifāt al-ḅayy)}

As we have seen, each class of living beings is distinct from other classes by the specific and uniform configuration of its bodily structure and form. The structure depends on the arrangement of the body's constituent atoms, which is determined by the accidents of location (akwān) that inhere in each atom. The further attributes that contribute to the external and internal form are explained by colour and probably other accidents such as moistness, dryness, softness and coarseness. It is the combination of the configuration of the atoms and these accidents that accounts for the four legs, head, tail, two eyes, heart, muscles, black and white stripes, etc. of, say, a zebra, and that, considering their uniformity and familiarity, alone justify referring to a particular object as "a zebra". As nothing other than the structure and the form enter into the definition of "zebra", even a dead zebra is still properly a "zebra". Likewise, a dead human being is still properly designated "man". ${ }^{4}$

None of these visible features, however, account for the basic distinction that al-Baghdādī makes between animate and inanimate bodily objects in his foregoing taxonomy. This distinction is instead analysed in terms of special attributes that are

\footnotetext{
${ }^{46}$ Ibn Fūrak, Mujarrad, 215. Al-Asharī's position is also reported by al-Fazārī (Sharh al-Irshād, f. 104a). ${ }^{47}$ Al-Fazārī, Sharh al-Irshād, f. 104a; cf. al-Anșārī, Ghunya, f. 156b; al-Makkī, Nihāya, f. 87b. The Bașran Mu tazila, by contrast, do not seem to include "internal form" as such in their definition of "man", though some clarify the definition by stating that the bodily structure must comprise flesh, moisture and life. According to Ibn Mattawayh (al-Tadhkira fì aḥkām al-jawāhir wa-l-árād, ed. D. Gimaret, 2 vols. [Cairo: Institut Français d'Archéologie Orientale, 2009], 2, 371-2), al-Jubbā'ì did not account for the latter elements in his definition, but his son Abū Hāshim did and hence maintained that "man" could not designate an anthropomorphic sculpture. 'Abd al-Jabbār, however, cites al-Jubbā' 1 opining that it is unlikely $(y a b u d)$ that a sculpture can be designated "a man", since it does not consist of flesh and blood (al-Mughnì fì abwāb al-tawhị̂d wa-l-adl, 11. al-Taklīf, ed. M. 'A. al-Najjār and 'A. al-Najjār [Cairo: al-Dār al-Mișriyya li-l-Ta'līf wa-l-Tarjama, 1965], 312).

${ }^{48}$ Al-Kalābādhī, Baḥr al-fawā̉ id, ed. W. K. Zakī, 2 vols. (Cairo: Dār al-Salām, 2008), 1, 543 ff., esp. 547-8 (partially cited in al-Fazārī, Sharh al-Irshāad, f. 104a). Al-Kalābādhī's discussion exhibits non-kalām influences that go beyond our present scope.

${ }^{49}$ Al-Anșārī, Ghunya, f. 156b. This agrees with the Bahshamī position ('Abd al-Jabbār, Mughnī, 11, 364).

(c) 2012 Hartford Seminary. 
categorically specific to animate beings (sg. hayy, hayawān) to the exclusion of inanimate beings (sg. jamād), which are known as the "animate being's attributes" (sifät al-hayy). ${ }^{50}$ In the case of living bodily objects, each attribute (sifa) is accounted for, in modular fashion, by a distinct accident that inheres in the atom and acts as a cause that

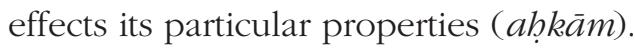

Of these attributes specific to animate being, the most primary is the attribute of life ( hayāt), which is homogenous in all created animate beings - humans, angels, jinn, demons and animals alike - that is to say, all instances of the accident of life belong to one and the same class (jins wāhidid). "Life", according to al-Baghdādī, is defined by Asharāis in two main ways. Some define it as "an attribute by which the living being is living". In other words, it is a specific entitative determinant ( $\left.m a^{\prime} n \bar{a}\right)$ that makes the being to which it is particular a living being. Other members of the school define "life" as,

... an attribute that, by the existence of which, [it becomes possible that] knowledge, capacity and will exist in that to which it [is an attribute of] life. If each one of these attributes is used separately [in the definition] — such that we say, "life is what acts as a condition (shart) for the existence of capacity", or "what is a condition for the existence of knowledge", or "what is a condition for the existence of will" - the definition will still be correct. This is sound according to our principles, since our school-members agree unanimously that the existence of neither knowledge, capacity nor will would be possible (la yașị̧ living. ${ }^{52}$

In this vein, Ibn Fürak defines life as "that by the existence of which the perception of the objects of perception becomes possible". 53 This definition invokes the central characteristic property of life, namely that it effects, in the entity in which it inheres, the possibility (siḥha) of the existence of the other attributes specific to animate beings. Life, hence, is a condition (shart, musaḥhih) the existence of which the existence of each of these other attributes depends (yaftaqiru) on, or requires (yaqtadi ), and by which it becomes possible (yasiḅhu). ${ }^{54}$ It "is a condition for knowledge, will, capacity, their particular contraries ( $\bar{a} d d \bar{a} d i-h \bar{a} a l-k h \bar{a} s ̦ s a)$ and every other attribute (wasf) of which only a living being can be attributed". ${ }^{55}$ It is also a condition for perception, including

${ }^{50}$ For instance, Ibn Fūrak, Mujarrad, 68; 86; al-Baghdādī, Asmǟ, f. 15 b.

${ }^{51}$ Al-Baghdādī, Ușūl, 105. This contrasts with, say, the accidents of colour and taste, which comprise heterogeneous classes.

${ }^{52}$ Al-Baghdādī, Asmā', f. 123b; cf. f. 203b.

${ }^{53}$ Ibn Fūrak, al-Hudūd fì l-ușūl, ed. M. Abdel Haleem, in "Early Islamic Theological and Juristic Terminology: Kitāb al-Hudūd fì l-Ușül by Ibn Fūrak," Bulletin of the School of Oriental and African Studies 54.1 (1991): 4-41, at 23.

${ }^{54}$ Ibn Fūrak, Mujarrad, 260; al-Baghdādī, Ușūl, 28-9; 105; idem., Farq, 325; al-Juwaynī, Shāmil, 672; 708-11; al-Anșārī, Ghunya, f. 51a; idem., Sharh al-Irshād (MS Princeton), f. 50a. On that the terms "sharț" and "muṣaḥhịh" are identical, see al-Juwaynī, Shāmil, 710.

55 Al-Juwaynī, Shāmil, 711. In contrast, say, to erroneous conviction ( $j a h l)$, death is a "general contrary", but not a "particular contrary", to each of knowledge, will and capacity (al-Juwaynī [Ibn al-Amīr], Ikhtiṣār, ff. 60a-b). The existence of death, hence, is not conditional upon the coexistence of life. 
sight and hearing, and for pleasure and pain. ${ }^{56} \mathrm{Al}-J u w a y n \overline{1}$ refers to all these as "attributes conditional upon life" (al-șifät al-mashrüța bi-l-ḥayāt). ${ }^{57}$ Opinions differed on whether speech depended on life. ${ }^{58}$

Underlining the notion that life is the most primary of the attributes specific to animate beings, al-Rāzī writes that,

... a being that is capable and knowing must invariably be living. For predicating (wasf) it as "living" is more general, given that there is many a being that is living but neither knowing nor capable. Restricted attributes (sg. wasf khāss) cannot be predicated [of a thing] unless the general attribute (wasf'a $\bar{a} m m$ ) is affirmed..$^{59}$

Life is the "general" attribute that encompasses absolutely all animate beings. The other attributes specific to animate beings are "restricted" in the sense that not all animate beings possess them.

Asharīs often contrast this doctrine with the positions of both the earlier Mutazili al-Șāliḥ̄ ( $f l$. late 3rd/9th c.), who maintained that attributes such as perception, knowledge, capacity, will, hearing, sight, pleasure and pain did not depend on the existence of life, but could exist in a dead object, and the Karrāmiyya who define life as capacity and opine that though a human being loses his capacity when he dies he continues both to perceive and to know. They were also aware that they shared this doctrine with most Mutazila, but with one important qualification: for Asharīs, though life is a condition for other attributes, it never causes, or necessitates, (awjabat, aththarat) them. ${ }^{60}$ Al-Juwaynī, for instance, criticises the Bahshami doctrine that the presence of the attribute of life and the absence of bodily defects in an object necessitate (müjib) perception. ${ }^{61}$ Likewise, knowledge is not necessitated by life; for there can be life without knowledge. ${ }^{2}$ Philosophical and medical theories (normally ascribed to the

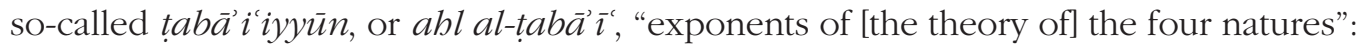
heat, coldness, moisture and dryness) that explain the somatic and psychosomatic functions of living entities in terms of causally-intertwined properties intrinsic to substances are subjected to severe criticism.

\footnotetext{
${ }^{56}$ Al-Baghdādī, Asmā', ff. 126b-127a (section entitled, "on the entitative determinants for the existence of which life is a condition"). Al-Baghdādī reiterates that this doctrine is held unanimously by all Asháàis.

${ }^{57}$ For instance, al-Juwaynī (Ibn al-Amīr), Ikhtiṣār, ff. 61a; 137a.

${ }^{58}$ For instance, al-Baghdādī, Asmāà, ff. 123b; 128a; 138a; cf. Gimaret, La doctrine d'al-Ash'arī, 208.

${ }^{59} \mathrm{Al}-\mathrm{Rā} \overline{\mathrm{i}}$, Ușūl, f. 43b.

${ }^{60}$ For the Bahshamī position, see: Ibn Mattawayh, Tadhkira, 2, 416; 2, 446; 2, 526; 2, 699. On al-Șālihị̂, see: al-Baghdādī, Asmàa ,ff. 94a; 128a; cf. van Ess, Theologie und Gesellschaft, 4, 138-40. On the Karrāmī position, see: al-Baghdādī, Ușūl, 29; idem., Asmā', f. 128a; al-Rāzī, Ușūl, f. 43b.

${ }^{61}$ Al-Juwaynī, Shämil, 688-9. The discussion appears in the chapter on causes ('ilal) and appeals to more general doctrines on causes that go beyond the scope of the present paper. Cf. Ibn Mattawayh, Tadhkira, 2, 699-700.

${ }^{62}$ Al-Juwaynī, Shāmil, 708-9; al-Anșārī, Sharḥ al-Irshād (MS Princeton), ff. 50a-b.

(ㄷ) 2012 Hartford Seminary. 
The principle that life is a condition for the other attributes specific to animate beings is typically argued for from the attributes of knowledge and capacity as follows. If we reflect upon our observation of both beings that conceivably can be attributed (yasihịhu ittișäfu-hu) by knowledge and capacity and beings that can be predicated of neither, we will be able to discern, through the application of the method of "investigation and disjunction" (al-sabr wa-l-taqsim), that the only distinction that accounts for this difference between these two classes of beings is the attribute of life present in the former class but not in the latter. ${ }^{63}$ Life, hence, is a cause, or ground, ('illa) that effects the property $(\mathrm{bukm})$ of making the existence of knowledge and capacity possible. From this principle - a relatively-tangible item of knowledge relating to created things (al-shäbid), which may serve to make known, by way of analogy (qiyass), intangible facts about God ( $\left.a l-g h \vec{a}^{\prime} b\right)$ - Asharàs go on to establish that since God can be shown to be predicated of knowledge and capacity (He thus has the same hukm), it immediately follows that He must be living (He has the same 'illa). ${ }^{64}$ In the same vein, al-Baghdādi argues that, given his denial that life is a condition for knowledge, capacity and will, al-Ṣalihị will have no way of demonstrating that God is living. ${ }^{65}$ Along the same lines, it is then argued that since God is living, it will be conceivable for Him to have the attributes of hearing and sight. Al-Anșārīi writes:

It has been shown that the living being in the observable realm (shäbidan) is amenable to ( $q \bar{a} \bar{b}$ il $l i$-) being predicated of hearing and vision. Having established this, we then take the route of investigation and disjunction and say: An inanimate being is not amenable to being predicated of hearing and sight; but if it becomes predicated of life, it will become prepared (tahayya $a$ ) to receive both [attributes], if it does not bear a defect. If we then investigate the attributes of the living being with a view to identifying what makes it amenable to being predicated of hearing and sight, our investigation will illustrate that that can only be its being living. [. . .] If we prove that God, exalted, is living, we must consequently assert that He is predicated of hearing and sight. ${ }^{66}$

If, by contrast, the investigation results in that the condition for hearing and sight is the sense organ ( $h \bar{a} s s a$ ), it will become impossible to affirm that God hears or sees.

\footnotetext{
${ }^{63}$ Al-Juwaynī, Shāmil, 622. On investigation and disjunction, see, for instance: Josef van Ess, Die Erkenntnislebre des 'Adudaddin al-Īci (Wiesbaden: Franz Steiner, 1966), 394 ff.; Wael Hallaq, "The Development of Logical Structure in Sunni Legal Theory", Der Islam 64 (1987): 42-67, at 60-1; idem., "Logic, Formal Arguments and Formalization of Arguments in Sunnī Jurisprudence", Arabica 37 (1990): 315-58.

${ }^{64}$ Al-Baghdādī, Ușūl, 105; al-Juwaynī, Irshād, 63; al-Anșārī, Ghunya, f. 51a; Abū Bakr al-Fūrakī, al-Nizāmin fì l-ușūl (MS Istanbul, Süleymaniye Kütüphanesi, Ayasofya 2378), f. 41b. This is also, of course, the standard Mu tazilī proof that God is living (for instance, Mankdīm Shashdīw, Sharh al-Ușūl al-khamsa, ed. 'A. 'Uthmān [Cairo: Maktabat Wahba, 1965], 160 ff.).

${ }^{65}$ Al-Baghdādī, Asmā̀, f. 95b; cf. idem., Ușūl, 105; idem., Farq, 325.

${ }^{66}$ Al-Anșārī, Ghunya, f. 52b; cf. idem., Sharh al-Irshād (MS Princeton), f. 33b; al-Juwaynī, Irshād, 73; al-Mutawallī, Mughnī, 19-20.
} 
These stock arguments are encountered, in one form or another, in most kalām works in which God's attributes are argued for.

For classical Asharīis, death is an accident and as such a direct contrary (didd) of life. ${ }^{67}$ It is also a contrary of all other attributes of animate beings. ${ }^{68}$ This position is defended against both the Bahshamis and "some" philosophers who maintain that death is the mere privation of life (laysa manan akthar min 'adam al-ḥayāt). For the philosophers, hence, death is analogous to both the state of rest (sukün) and darkness, which they consider to be not things (laysa bi-shay'), but the mere privation of motion and light, respectively. In response, al-Baghdādi argues that this would entail the inadmissible consequent that even accidents can properly be said to be "dead" and "in a state of rest", since they cannot receive the accidents of life or motion. Likewise, al-Anșārī argues that had "dead" referred to the mere privation ('uruww) of life, it would have been correct to describe all accidents and inanimate beings as "dead" ${ }^{69}$ To al-Makkī, the Qur'ānic statement that God "created life and death" (67.2) attests to death being a "real existent" (mawjūd ḥaqīqu). ${ }^{70}$

The doctrine that death is an accident has a basis in the classical Asharī principle that an atom must contain an instance of each class (jins) of accidents or its contrary. ${ }^{71}$ There was a difference of opinion as to whether death was the only contrary of life. Some classical Ash'arīs distinguish between death and inanimateness (jamādiyya), and hence treat life, death and inanimateness as direct contraries of each other. ${ }^{72}$ Al-Baghdādī cites the Qur'ānic verse, "Every nafs will taste death" (3.185), as evidence that only spirit (nafs)-bearing beings die, to the exclusion of inanimate beings and accidents. ${ }^{73}$ For al-Juwaynī, however, death exists in all non-living beings, including inanimate beings that have not been, and will never be, animate, though it is uncustomary to describe these as "dead". Both the death present in the inanimate being that has never been

\footnotetext{
${ }^{67}$ Ibn Fūrak, Mujarrad, 216; al-Baghdādī, Ușūl, 43; al-Juwaynī (Ibn al-Amīr), Ikhtișār, ff. 60a-b. The meaning of the divine name "Mumît" is "He who creates death in what He causes to die" (al-Baghdādī, $A s m \vec{a}$, f. 203a). Like the accident of life, death is homogenous (idem., Asmä, f. 204a). The distinct accident of killing (qatl) subsists in the killer, not the entity killed (idem., Ușūl, 43; on the earlier debate on killing, see al-Asháàī, Maqālāt, 408; 421 ff.).

${ }^{68}$ Ibn Fūrak, Mujarrad, 266; al-Baghdādī, Asmā̄, f. 203b.

${ }^{69}$ Al-Baghdādī, Ușūl, 43; idem., Asmā̄, ff. 203b-204a; al-Anșārī, Ghunya, f. 154b (reading allatī lā hạāt fì-hā mawșūfa bi-anna-hā mayyita; also paraphrased by al-Makkī, Nihāya, f. 84b). For the Bahshamī position, see Ibn Mattawayh, Tadbkira, 2, $404 \mathrm{ff}$. In viewing death as an accident, the Asharīs were in agreement with the Baghdādī Mu'tazila (Abū Rashīd al-Naysābūrī, al-Masā il fì l-khilāf bayna l-bașriyyīn wa-l-baghdādiyyīn, ed. M. Ziyāda and R. al-Sayyid [Tripoli, Libya: Ma had al-Inmā' al-Arabī, 1979], 235 ff.) and Abū 'Alī al-Jubbā'ì (Ibn Mattawayh, Tadhkira, 2, 404-5).

${ }^{70}$ Al-Makkī, Nihāya, f. 84b; cf. al-Rāzī, al-Tafsīr al-kabīr, 32 vols. in 16 (Beirut: Dār al-Fikr, 1981), 30, 54. The verse was also cited by al-Jubbā'̀̄ in support of this doctrine (Ibn Mattawayh, Tadhkira, 2, 406).

${ }^{71}$ For instance, al-Harrāsī, Ușūl, f. $41 \mathrm{a}$.

${ }^{72}$ Al-Baghdādī, Ușūl, 43; idem., Asmäa', f. 203b. He attributes this position simply to "our school-members" (aṣhạabu-nā).

${ }^{73}$ Al-Baghdādī, Asmà̄ ff. 204a-b. Asháarì conceptions of the spirit are discussed below. 
animate $(j a m \bar{a} d)$ and that which occurs in a previously-living being (hayawān) are homogeneous. ${ }^{74}$

Yet even if it is distinguished from inanimateness, death need not be preceded by life. ${ }^{75}$ Asharīs often maintained that in its initial phases of formation, that is, when it begins as sperm in the womb and during the earliest stage of its foetal development, the human body is dead. When the spirit is then instilled in the foetus, when it is four-months old, its atoms become endowed with the accident of life, which replaces the accident of death. When the body then dies, the atoms once more receive the accident of death, which replaces life; and when the body is resurrected life replaces death for the final time. This explains the Qur'annic verse, "Twice You have made us dead, and twice You have brought us to life" (40.11). ${ }^{76}$

To say that a bodily object is "living" does not imply that instances of the accident of life exist in all of its atoms. In unsound bodies, life may inhere in the atoms comprising only some parts of the body, while death will inhere in atoms comprising other parts. ${ }^{77}$ Yet even sound bodies, according to most classical Asharīis, are only partly animate. Opinions differed on whether hair and bones were living: a debate that was of especial interest to jurists, who sought to determine whether these substances were religiously pure or impure. ${ }^{78}$ One widely-accepted criterion is that parts that cannot perceive pain are inanimate, which rests on the principles that life is the only condition for the perception of pain and that this class of perception is the only animate attribute, other than life, that normally can occur in any living part of the body. Al-Bāqillānī, and following him al-Juwaynī, favoured the view that "hair bears no signs ( dala $i l$ ) of life", most evidently as it cannot be a locus for pain. Hair growth does not presuppose life; for plants too grow, but are deemed to be inanimate. Bones were a more problematic case, as it was difficult to ascertain whether or not they could experience pain. If it is asserted that they do experience pain, then they will be living. Otherwise, if pain is experienced only in the nerves that interpenetrate bones, that would suggest that bones are not living. ${ }^{79}$

\footnotetext{
${ }^{74}$ Al-Juwaynī (Ibn al-Amīr), Ikhtiṣār, f. 60b. Likewise, al-Bāqillānī (Inșāf, 30) identifies both "lifeless beings (mawāt) and accidents" as "inanimate beings (jamādāt), which are devoid of life", which implies that he makes no distinction between death and inanimateness.

${ }^{75}$ Ibn Fūrak, Hudūd, 23; al-Juwaynī (Ibn al-Amīr), Ikhtișār, f. 60b.

${ }^{76}$ Al-Baghdādī, Asmāà, ff. 203a; 234a. The Māturīdī, Abū Isḥāq Ibrāhīm al-Ṣaffār (d. 534/1139) adduces, "You were dead, then He gave you life" (Q. 2.28) (Talkhīṣ al-adilla li-qawāid al-tawhị̂d, ed. A. Brodersen, 2 vols. [Beirut: Orient-Institut, 2011], 1, 246-7).

${ }_{77}$ Al-Baghdādī, Ușūl, 29.

${ }^{78}$ Al-Juwaynī (Ibn al-Amīr), Ikhtișār, f. 60b; cf. f. 201b. For representative eleventh-century juristic discussions of this question see: al-Juwaynī, Nihāyat al-mațlab fì dirāyat al-madhhab, ed. 'A. M. al-Dīb, 14 vols. (Beirut: Dār al-Minhāj, 2007), 1, 30-1; 1, 36 (where al-Juwaynī notes that this subject belongs properly to latîf al-kalām, that is, theological investigations of the nature of created beings, in contrast to jalìl al-kalām, which is more concerned with divine and cosmic matters); and 'Alī ibn Muḥammad al-Māwardī, al-Ḥāwi al-kabìr, ed. M. Masțarjī, 24 vols. (Beirut: Dār al-Fikr, 1994), 1, 73 ff. ${ }^{79}$ The association made between life and pain is borrowed from the Bașran Mu tazila. See, for instance: 'Abd al-Jabbār, Mughnī, 11, 311 ff.; 11, 335-7; cf. Heemskerk, "Abd al-Jabbār," 132.
} 
Other accidents of animate beings normally occur in specific parts of the body. Knowledge, for instance, normally occurs in the heart, which according to al-Juwayni, is confirmed by scriptural evidence: namely, several Qur'ānic verses that make the heart central to man, especially as the locus of belief (e.g. 50.37), and "commands" (amr) (probably not exclusively revealed) which associate evil thoughts and motives (wiswās, khātir, häjis) with the heart. ${ }^{80}$ This cardiocentrism is defended against the physicians' theory that knowledge occurs in the brain, for which they attest anatomical evidence. ${ }^{81}$ Yet al-Juwaynī and, as he reports, most other Asharīis also accept that it is conceivable for knowledge to exist in other loci within the body. For when sensory perception, which again can occur in any living part of the body, occurs in an atom, it will be followed by an accident of knowledge that occurs in the same atom, which then becomes both a "perceiver" (mudrik) and a "knower" ('älim). In the normal course of events ( $\bar{a} d a$ ), an instance of knowledge - whose content is that an instance of perception has occurred in a certain part of the body - may subsequently occur in an atom within the heart. ${ }^{82} \mathrm{~A}$ more detailed exploration of the properties and workings of each of the attributes specific to the living being is beyond the scope of the present article.

\section{Bodily Structure (binya)}

As mentioned earlier, a created "thing" (shay'), in both Bașran Mutazilism and Ashárism, can be either an atom or an accident. ${ }^{83} \mathrm{~A}$ composite body, strictly speaking, is thus not a thing, but an agglomeration of multiple things, especially, as already pointed out, that the whole would lack a unifying essence. In earlier (pre-Bahshamī and pre-Ashárī) Bașran Mútazilism, an instance of an accident can only qualify a single atom.

${ }^{80}$ Al-Juwaynī (Ibn al-Amīr), Ikhtiṣār, ff. 60b-61a; cf. f. 107a; al-Bāqillān̄̄, Inșāf, 52; al-Makkī, Nihāya, f. 86a. See also p. 461 ff. below. For a Bahshamī view, see 'Abd al-Jabbār, Mughnī, 11, 365; Heemskerk, "Abd al-Jabbār," 133.

${ }^{81}$ Al-Juwaynī (Ibn al-Amīr), Ikhtișār, ff. 60b-61a. However, in his later work the Nizāmiyya (246-7), he writes in the section on the punishment in the grave that "the cognizant part (al-fähim) of man in the present life consists of subtle particles located in ( ajzà latîfa fî̀) either his heart or brain, whereas the organs of action are employed (mustakhdam) by those cognizant and managing (mudabbir) particles. The hand, leg, flesh, muscles and bones possess no knowledge themselves". These "subtle particles" seem to be certain atoms in, or probably of, the heart or the brain and should not be identified with the spirit (cf. p. $470 \mathrm{ff}$. below), since al-Juwaynī adds that the spirit will be "returned" to them in the grave. In the Irshäd (376), the subject of the inquisition in the grave is said to be particles "of either the heart or another" part of the body (mina l-qalb aw ghayri-bi), though these are not afforded any cognitive role in the present life. Many of the views put forth in the Nizämiyya, it should be added, differ from al-Juwaynī's earlier views and were shunned in early-6th/12th-century Asharism. On Galenic encephalocentrism, see, for instance: Julius Rocca, Galen on the Brain: Anatomical Knowledge and Physiological Speculation in the Second Century AD (Leiden and Boston: E.J. Brill, 2003).

${ }^{82}$ Al-Juwaynī (Ibn al-Amīr), Ikhtișār, ff. 60b-61a.

${ }^{83}$ See p. 438 above.

(C) 2012 Hartford Seminary 
A bodily composite, therefore, would have no attributes that are particular to it as a whole, but would be no more than the sum total of its constituent atoms and their individual attributes.

To the Mutazila, however, this model left some crucial questions unanswered. Chief among those are ethical questions that revolve around the definition of the obligated agent (mukallaf). For man must be responsible for his acts, according to the Mu'tazili theory of justice, as a single unity, not as individual atoms or organs. Knowledge and motives, for instance, exist in the heart, but can result in an evil act that takes place in the arm; yet another part or even the entire body might be justly punished either in this world or in the afterlife. This shows that the true agent that bears full responsibility for the act is the whole bodily composite, not just the arm or the heart. Abū 'Alī al-Jubbā' $\overline{1}$ (d. 303/915), hence, maintained that the living being was somehow a unity, though it appears that he lacked the ontological apparatus to explain exactly how knowledge and action could be predicated of the whole composite, not just of the atoms of the heart or a limb. ${ }^{84}$

The solution to this problem was proposed by his son Abū Hāshim al-Jubbā'̄ (d. 321/933), who introduced the concept of the "state" ( $b \bar{a} l$ ) as an ontologically-real attribute (sifa) that qualifies an entity. ${ }^{85}$ To say that a corporeal thing is living (bayy) hence denotes, not the presence in it of the accident of life, but "its being living" (kawnu-hu hayyan), a state that the accident of life engenders ${ }^{86}$ Abū Hāshim also distinguished between accidents that qualified only the individual atom in which they inhered, and accidents that engendered an attribute, or a state, for the whole composite body. The latter class of accidents includes life and the accidents conditional upon it. ${ }^{87}$ And it is the composite body's "being living", by virtue of the accident of life that inheres in most of its atoms, that makes the whole have "the character of a single thing" ( $f i \mathrm{hukm}$, or bi-manzilat al-shay' al-wähid), that is, a unity. ${ }^{88}$ This unity allows the Bahshamis to speak of the individual man as being, strictly speaking, a single voluntary agent ( $m u r i d$ ), a knower ('älim) and a perceiver (mudrik).

However, the relation between the accidents specific to living beings and the composite body as a whole is also one of mutual dependence. The very accidents that engender an attribute for the whole composite body (jumla) that has a structure (binya) specific to its class of animate beings also depend on this structure for their existence. A sound bodily structure, and indeed the presence of moisture (rutüba, billa) in the body, are each a condition (shart) for the existence of life. ${ }^{89}$ The inseparable connection

\footnotetext{
${ }^{84}$ See Frank, Beings and their Attributes, 42.

${ }^{85}$ On the Bahshamī theory of states, see: Frank, Beings and their Attributes, $20 \mathrm{ff}$.; Ahmed Alami, L'ontologie modale: Étude de la théorie des modes d'Abū Hāšim al-Ǧubbā̀i (Paris: Vrin, 2001); "Hāl," EI2.

${ }^{86}$ Ibn Mattawayh, Tadhkira, 2, 369-71; cf. Frank, Beings and their Attributes, 44-5.

${ }^{87}$ Ibn Mattawayh, Tadhkira, 2, 411; 2, 524; 2, 697-8; cf. Frank, Beings and their Attributes, 45.

${ }^{88}$ Ibn Mattawayh, Tadhkira, 2, 370; 'Abd al-Jabbār, Mughnī, 11, 352.

${ }^{89}$ Ibn Mattawayh, Tadhkira, 2, 383-6; 'Abd al-Jabbār, Mughnī, 11, 354.
} 
between the two doctrines is indicated explicitly by the Bahshamī Ibn Mattawayh, who writes in the course of listing the various primary divisions of accidents, that accidents,

... that exist in a single substratum ${ }^{90}$ divide into those that require (iftaqara ila $)$ bodily structure, and those that do not. The former are all those that engender

(iqtad $\bar{a}$ ) an attribute for the composite body. The latter are all those that do not. ${ }^{91}$

Elsewhere, he argues for the dependence of the existence of life on structure from the doctrine that life qualifies the composite whole as a unity, as follows. ${ }^{92}$ If it is conceivable for the accident of life to exist in a solitary atom, it would qualify that atom as living. If further atoms are then joined to that atom, that instance of the accident of life would continue to qualify that atom in which it subsists, and would not extend its effect to these other atoms. Therefore, if each of these atoms had its own individual accident of life, their sum total would be an agglomeration of multiple discrete living beings ( $a b y \hat{a} \overrightarrow{)}$ ). However, we already know that the living being is a unity. From this, Ibn Mattawayh infers that life cannot subsist in an individual atom, but requires the presence of a sound bodily structure.

Both doctrines are opposed by classical Asharīs, who argue against the possibility of an inherent causative relation between the individual accident and the composite body as a whole. This stance traditionally finds expression in two doctrines, the antitheses of the Bahshamī propositions:

A1. The existence of an accident specific to animate beings in an atom is not conditional upon the atom being part of a bodily structure.

A2. An instance of an accident specific to animate beings only qualifies the atom in which it inheres, never the whole bodily composite of which the atom is part.

Bodily structure, hence, is never a condition (shart) for the existence of an accident, which in turn is never a cause ('illa) for any bodily attributes. Reflecting their adversaries' position, Asharīs too consider the two doctrines inseparable. From A2, it is then contended:

A3. The individual human being is not a unity.

As a bodily composite, man is nothing more than the sum of its constituent atoms and accidents. Let us consider A1 and A2 first, before turning (in section 4.2) to A3.

\subsection{Accidents are Particular to Atoms, Never to Bodies}

\section{i. Al-Ashiarī and al-Qalānisī}

Classical Asharīis argue that life depends on neither specific bodily structure (binya makhșūssa) nor moistness (billa, ruțüba), but instead can inhere in any self-subsistent

\footnotetext{
${ }^{90}$ As opposed to the accident of composition ( $t a^{\prime} l i f$ ), which exists in two atoms.

${ }^{91}$ Ibn Mattawayh, Tadhkira, 1, 2.

${ }^{92}$ Ibn Mattawayh, Tadhkira, 2, 383.

C 2012 Hartford Seminary.
} 
being, even in a solitary atom. ${ }^{93}$ The same is true of other animate attributes, which are furthermore not conditional on the presence of bodily instruments $(\bar{a} l a)$ or sense organs ( hạassa). ${ }^{94}$ Ibn Fūrak reports that al-Ash'arī,

... asserted that none of these entitative determinants [particular to animate beings] requires a bodily structure, in contrast to our adversaries' claim that life requires a specific structure (for instance the structure of man or another animate being), such that if the head becomes disconnected from the body the existence of [life] would become impossible, just as [life] requires a substratum, in the absence of which its existence would be impossible.

He also maintained that life can exist in a solitary atom (juz munfarid), that separateness (iftirāq) is not contrary to life, and that life can exist in any form of composition (tarkīb) whatsoever. And he maintained that life does not require moistness to exist. ${ }^{95}$

Readily discernible evidence attesting to this doctrine (A1), Asharīis point out, can be seen in that God can create life in things so small as a gnat or so big as an elephant, and that various insects are possessed of life and perception despite lacking our human bodily structure. ${ }^{96}$ As evidence that the soundness of bodily structure is unnecessary for life, they cite, for instance, the cases of the snake that when cut into pieces continues to move, the body of the decapitated person which purportedly convulses for a short while following decapitation, and the severely-injured person who continues to live for a few days despite having an unsound bodily structure. ${ }^{97}$ Notwithstanding, Asharīs recognise that, in the normal course of events (' $\bar{a} d a$ ), life is negated when bodily structure becomes defective just as it becomes negated in the absence of nourishment. ${ }^{98}$ In itself, however, the normal courses of events (' $\bar{a} d \bar{a} t$ ) do not constitute sufficient evidence for life's dependence on structure, which instead should be shown to be either known immediately (darüra) or established discursively using proofs ( nazar wa-istidlāl). ${ }^{99}$

Apart from removing a constraint from God's creative power and underpinning the related doctrine that accidents cannot qualify composite bodies, the doctrine that animate accidents do not require bodily structure is significant in broader Asharā theology in at least two further respects. It is appealed to in defence of the Ashari doctrine that the divine attributes of life, knowledge, capacity, sight and hearing are entitative determinants and as such ontologically distinct from God's essence, against the

\footnotetext{
${ }^{93}$ For instance, Ibn Fūrak, Mujarrad, 170; 205; 266; al-Baghdādī, Ușūl, 105; 28-9; idem., Asmāa , f. 203b; al-Anșārīi, Ghunya, f. 154a.

${ }^{94}$ For instance, al-Juwaynī (Ibn al-Amīr), Ikhtiṣār, ff. 104b (speech); 125b-126a and 128a ff. (perception); 142a-b (capacity).

95 Ibn Fūrak, Mujarrad, 266.

${ }^{96}$ Al-Fūrakī, Niz̄āmī, f. 128b; al-Anșārī, Ghunya, f. 155a; cf. al-Mutawallī, Mughnī, 56. This, of course, presupposes that life in all these creatures is homogenous.

${ }_{97}$ Al-Baghdādī, Ușūl, 30; al-Fūrakī, Niẓāmīi, ff. 128a-b.

${ }^{98}$ Al-Baghdādī, Ușūl, 29-30.

${ }^{99}$ Al-Juwaynī (Ibn al-Amīr), Ikhtiṣār, f. 126a.
} 
Mútazili criticism that had these been entitative determinants they would have required a bodily structure in which to inhere, and in some cases they would have also been conditional on the presence of bodily instruments or sense organs. ${ }^{100}$ The doctrine also proved instrumental in discussions of the inquisition and torment experienced in the grave by decomposed bodies or small bodily fragments. Classical Asharīs argued that since animate attributes are not dependent on sound bodily structure, God can create life, knowledge, speech and other necessary attributes in some of the atoms of the body, allowing this process to take place. ${ }^{101}$

The related doctrine (A2) that an accident can only qualify an atom, never a composite body, and engender for it an attribute (sifa) can again be traced back to al-Asháaī. He reportedly held that "living", "perceiver", "knower" and "capable" can only designate, strictly speaking, the atom in which, respectively, life, perception, knowledge and capacity inhere. ${ }^{102}$ This is implied when Asharīs often state that "living" denotes "that in which life inheres" ( $m \bar{a}$ qāmat bi-hi l-hayāt); "acquirer" denotes "that in which acquisition inheres"; and so forth. ${ }^{103}$ Al-Baghdādī reports al-Asharā's position, accepted across the school, as follows:

According to him, the one living, capable, knowing and willing, in this world ( al-shāhid), is the atom in which knowledge, volition, capacity and life subsist. Composites cannot be predicated of ( lā tastahiqqu) these attributes (awșāf) by the inherence of these attributes in parts thereof, just as a composite does not become black or moving by the inherence of blackness and motion in a part thereof. Rather, it is the atom in which blackness and motion subsist, to the exclusion of all adjacent atoms, that will become black and moving by virtue of the blackness and motion that subsist therein. ${ }^{104}$

When the designations derived ( mushtaqq) from "life", "knowledge" and other accidents are predicated of a composite body, they are used in a figurative (majāz), rather than a literal ( haqiqa), sense. Even when life inheres in all of the atoms that constitute the composite, al-Ashari 1 would say that it is each individual atom, rather than the composite as a whole, that is living. ${ }^{105}$

\footnotetext{
${ }^{100}$ See, for instance: al-Juwaynī (Ibn al-Amīr), Iktișār, ff. 125b-126a ("Had the structure been a condition for [perception], the Pre-eternal Being would not have been a perceiver; for conditions must be applied equally at both the observable and unobservable levels [al-shurūtyajibu tardu-hā shāhidan wa-ghä'iban]"); al-Anșārī, Sharḥ al-Irshād (MS Princeton), ff. 66b-67a; idem., Ghunya, f. 154b. For the Mutazila, speech does not require structure (Ibn Mattawayh, Tadhkira, 1, $187 \mathrm{ff}$.), while will can exist without inhering in a substratum.

${ }^{101}$ Ibn Fūrak, Mujarrad, 170; al-Fūrakī, Niẓāmī, f. 127b; al-Rāzī, Ușūl, ff. 177a-178a; cf. the Māturīdī al-Șaffār, Talkhiș al-adilla, 1, 248-50. The inquisition most likely occurs in some of the atoms of the heart (al-Juwaynī, Irshād, 376), or in either the heart or the brain (al-Anșāīi, Ghunya, f. 216a).

${ }^{102}$ Ibn Fūrak, Mujarrad, 263.

${ }^{103}$ For instance, Ibn Fūrak, Mujarrad, 108; 146; 205; 263; cf. al-Baghdādī, Asmä, f. $124 a$.

${ }^{104}$ Al-Baghdādī, $A s m \bar{a}$, f. 36a.

${ }^{105}$ Al-Baghdādī, Asmä’, ff. 127a; 129b.

(C) 2012 Hartford Seminary 
The defence of this doctrine is coupled with the criticism of the Mu tazili theory that animate attributes are properly predicated of the whole composite of the human body. According to Ibn Fūrak:

[Al-Asharīi] used to maintain that the doctrines, espoused by the Mutazila, [1] that man is this [external] composite, and [2] that it is this composite that acts and is living and capable, prove to be weak when examined with respect to their own principal doctrines $(\bar{u} s \bar{u} l)$. [He maintained] also that the doctrine, espoused by some of them, [3] that what is living and capable is the individual atom, is more consistent and sounder when examined with respect to their principal doctrines. ${ }^{106}$

Al-Asharā reproduces objections against doctrines 1 and 2 put forth by Mutazilī exponents of doctrine 3, that man is an atom. ${ }^{107}$ He reportedly "used to judge in favour of those who asserted that man is a single indivisible atom, against those Mu tazilīs who held" doctrines 1 and $2,{ }^{108}$ including, of course, his teacher al-Jubbā' $\overline{1}$. This was only a tactic to demonstrate that doctrines 1 and 2 are inconsistent. Dialectic aside, al-Ashara $\overline{1}$ accepted doctrine 1 and opposed 2 and 3.

The main objection al-Asharī reproduces can be summarised as follows. If we postulate a composite body, in which life inheres in some parts and death, the contrary of life, inheres in other parts, then each of life and death will qualify the part (ba'd), the whole (al-kamäl), or neither the part nor the whole, in one of the following configurations:

i. The whole is living, and the whole is dead. However, it is inconceivable for an object to be qualified at once by contraries.

ii. The part in which death inheres is not dead (and either the whole, or the part in which life inheres, is living). This, however, is inconceivable, as it would follow that the part in which motion inheres is not moving.

iii. The part in which life inheres is living, and the part in which death inheres is dead. This is al-Asharî's own position, which the Mutazila eventually have to concede.

iv. The part in which life inheres is not living (and either the whole, or the part in which death inheres, is dead). This, however, is inconceivable, as it would imply that although the part in which incapacity ( $a j z$ ), which is analogous to death, inheres becomes incapable, the part in which capacity, which is analogous to life, inheres is not capable.

As evident from later Ashari versions of this argument from death against the doctrine that an attribute can qualify the whole composite, the argument draws its force from the notion that if the reality of death is conceded, it must have properties ( $a b \underline{k} \bar{a} m)$ cognate to those of life, its direct contrary. "According to us", al-Anșārī writes, "there is no

\footnotetext{
${ }^{106}$ Ibn Fūrak, Mujarrad, 215.

${ }^{107}$ Ibn Fūrak, Mujarrad, 215-17 (p. 216, ln. 3, reading al-jumla instead of al-juz').

${ }^{108}$ Ibn Fūrak, Mujarrad, 217. The text does not identify the exponents of doctrine 3. Elsewhere, al-Ashárī attributes this position to al-Ṣāliḥī (Maqālāt, 332; cf. van Ess, Theologie und Gesellschaft, 4, 139-40).
} 
difference ( farq) between death and life, because they are contraries (didd)" ${ }^{109}$ If conceded, such equivalence between the properties of death and life would force the opponents to concede either i or iii.

Al-Asharî̀'s objection from death targets Abū 'Alī al-Jubbā'̄ì and other earlier Mútazilīs who hold that death is a real entity. Later Asharā sources couple this objection with arguments against the view of Abū Hāshim, al-Asharī's contemporary, and his followers that death is the mere privation of life and hence not an accident. These have been discussed above. ${ }^{110}$

Aside from the Mutazila, Ibn Fūrak transmits a comparatively amiable objection that al-Asharā directs at some unnamed theologians with whom he associates himself (așhābu-nā), who hold that "man", or "the composite totality of man" (jumlat al-insān), "is capable", "is living", and "is the acquirer (muktasib)". In contrast, he asserted that the individual atom is in fact the object predicated of the attributes and hence the designations "capable" and "living", since capacity and life only inhere in the atom, which consequently is the entity predicated of the designations "acquirer", "obedient" ( $m u t \bar{\imath} \bar{\imath}$ ), "disobedient" ('asșî), "object of reward" (muthāb) and "object of punishment" (mu'āqab). ${ }^{111} \mathrm{Al}$-Baghdādī identifies these figures as Ibn Kullāb (d. 241/855), al-Qalānisī (3rd/9th c.) "and their followers", who designate the composite whole as the "wrongdoer" (zālim), "knower" and "capable", even though wrongdoing, knowledge and capacity exist only in some parts of the body. ${ }^{112}$ Al-Qalānisī is said to have maintained that "the attributes derived from (al-wasf al-mushtaqq min) life, knowledge and capacity" apply to the composite whole, though the accidents subsist only in parts thereof. ${ }^{113}$

Although this position appears in the first instance to coincide with the Mutazili thesis on the unity of man, al-Baghdādī interprets it in accordance with the standard Asharā position (A2 and A3). For in one place, he distinguishes between two positions taken by "fellow theologians" (așhāabu-nā), the first being al-Ash'arī's doctrine that attributes (wasf) such as life, knowledge and volition qualify only the atoms in which they inhere, rather than composite bodies. In the second position, which is not attributed here to any named figures, "the composite whole of man is one living [object] and one knower" (ḥayy wāḥid 'ālim wāḥid). Nonetheless,

These designations ( ism) apply to the composite whole of man, not because of the combination (ijtimā) of its atoms, but because God, may He be exalted and glorified, assigned (khașsa) them to it [that is, the composite whole], and applied

\footnotetext{
${ }^{109}$ Al-Anșārī, Ghunya, f. 154b; paraphrased by al-Makkī, Nihāya, f. 84b.

${ }^{110}$ See above, p. 447-8. For a Bahshamī response to the argument from death, see 'Abd al-Jabbār, Mughni, 11, 355-6.

${ }^{111}$ Ibn Fūrak, Mujarrad, 108; 134; 146; cf. Gimaret, La doctrine d'al-Ash'arī, 96-7.

${ }^{112}$ Al-Baghdādī, Ușūl, 132; idem., Asmāà, f. 170b. On Ibn Kullāb, see van Ess, Theologie und Gesellschaft, 4, 180 ff. On al-Qalānisī, see Daniel Gimaret, "Cet autre théologien sunnite: Abū l-Abbās al-Qalānisī," Journal Asiatique 277 (1989): 227-61, esp. at 247-8.

${ }^{113}$ Al-Baghdādī, Asmā̄, f. 127a; cf. ff. 129b; 299b.

(c) 2012 Hartford Seminary. 
these designations to the totality of [man's] atoms. Were he to separate his atoms and make each of these atoms living, knowing and capable, that would be conceivable and sound. ${ }^{114}$

Hence, a designation (ism) that should, strictly speaking, denote an attribute (sifa) that qualifies an atom can be validly predicated of the composite body as a whole, but only on account of divine assignment. Whether or not al-Baghdādī intends his interpretation to reflect the position of Ibn Kullāb and al-Qalānisī is not entirely clear. That in two other places, he reports that al-Qalānisī held that the accidents specific to animate beings can inhere in a solitary atom (and hence agreed with A1), ${ }^{115}$ suggests that al-Asharî's disagreement with al-Qalānisī is not ontological, but semantic.

\section{ii. Later Classical Ash'arīs}

In contrast to al-Asharāi, his followers take into consideration the theory of states ( $h a \bar{a} l$ ), advocated by their school-founder's contemporary Abū Hāshim, particularly the distinction it posits between the classes of accidents that only qualify the atoms they inhere in and those that qualify the whole composite. Al-Bāqillānī and al-Juwaynī both give this distinction considerable attention partly, it seems, to highlight a major difference between the Bahshamī position and the version of the theory of states that they themselves put forth. ${ }^{116}$ Yet "he among our school-members who denies states", al-Juwayni points out, "need not go into this problem; for the knower's 'being a knower' (kawn al-älim 'äliman) to [this school-member] will mean nothing other than the subsistence of knowledge in it", i.e. in the entity that is a knower. ${ }^{117}$ This advice is heeded by his student al-Harrāsī, who dismisses the notion that an accident can qualify a composite on the ground that it presupposes the more fundamental theory of states, which he rejects in toto. ${ }^{118}$

Al-Bāqillānī introduces his Kitāb al-Insān, as al-Anșārī reports in the chapter on man in the Ghunya, by establishing that life does not require a bodily structure (A1). ${ }^{119}$ The main objection al-Bāqillānī articulates against the opposite thesis of the Mutazila does not attack it directly, but instead proceeds to target the related doctrine that an accident cannot qualify a composite body (A2). He starts with the premise that accidents cannot inhere in more than one substratum ( maḥall) — that is, one atom ${ }^{120}$ — and from that sets out a dilemma, according to whether or not life engenders a state for that in which it is

\footnotetext{
${ }^{114}$ Al-Baghdādī, Asmāà, f. 36b.

${ }^{115}$ Al-Baghdādī, Asmā̄, ff. 127a; 129b.

${ }^{116}$ On their version of this theory, see: al-Juwaynī, Shāmil, 629 ff.; Ahmed Alami, "L'aš‘arisme face à la théorie des modes," Philosophie 77 (2003): 45-68; Daniel Gimaret, "La théorie des aḅwâl d'Abû Hâšim al-Ǧubbầî d'après des sources ašarites," in Journal asiatique 258 (1970): 47-86; "Hāl," EI2.

${ }^{117}$ Al-Juwaynī, Shāmil, 665.

${ }^{118}$ Al-Harrāsī, Ușūl, f. $43 \mathrm{a}$.

${ }^{119}$ Al-Anșārī, Ghunya, ff. 154a-b; paraphrased by al-Makkī, Nihāya, ff. 84a-b.

${ }^{120}$ As already mentioned, the Bahshamīs make one exception, namely the accident of composition $\left(t a^{\prime} l i f\right.$ ), which inheres in two contiguous atoms (see, for instance, Ibn Mattawayh, Tadhkira, 1, $289 \mathrm{ff}$.).
} 
present. If, in the first horn of the dilemma, it is conceded that the accident of life, like the accidents of colour and taste, does not engender a state, the living being would only be the atom in which life inheres. And it would follow that neither the body as a whole nor the atoms adjacent to this living atom would have any effect (athar) thereon. Though this last point is not justified, the reasoning behind it seems to be this: if a substratum fulfils all the conditions (shart) for a cause ('illa) to effect its properties ( $(\mathrm{ukm}$ ), it must be possible for the cause to exist in that substratum. In the second horn, if it is affirmed that the accident of life does engender a state, that state would only be engendered for the single atom in which life exists, and would not extend to other beings, be they connected to that atom within a bodily structure or entirely disconnected from it. For it is only to the being in which an accident exists and to which it is particular ( ikhtașs $a i-h i$ ) - that is, the single atom — that the accident engenders its properties. Otherwise, the accident would engender a state for atoms that exist outside the composite body of which it is part (an atom in the east, as al-Harrāsī puts it, would be qualified by an accident that inheres in an atom in the west), ${ }^{121}$ since the atom in which it inheres would have the same relation to them that it has to the other atoms that comprise the body. Al-Bāqillānī adduces that an accident that inheres in an atom, but affects the composite body, would be analogous to a hypothetical accident that exists in no substratum but which affects a number of random bodies: the aspect that the two cases have in common, and for which the former case should be deemed as inconceivable as the latter, is the absence of any particularity (ikhtișāss) connecting the accident to the atoms it affects. Contiguity (ittișa $l$ ), as opposed to separateness (infișa l), it is further pointed out, has no effect on the manner in which an accident engenders its properties.

Al-Bāqillānī's criticism is continued by al-Juwaynī, who lays out several objections against the notion of bodily states in a section on whether the properties ( $\mathrm{hukm}$ ) of a cause ('illa) are particular to its substratum or can extend to the composite body as a whole. ${ }^{122}$ His main objection is a developed version of al-Bāqillānī's argument from particularity (ikhtișâs). If it is not accepted that a cause only affects that to which it is particular, we would have to admit that a single cause could affect all the atoms of the world. So a cause must be particular to what it affects; and the only valid relation of particularity between the two is that the former inhere in the latter. The conjunction (ittișāl) between an atom that serves as the substratum of the cause and the composite body of which it is part is only a relation between an atom and a body and hence cannot be a valid relation of particularity between the cause and body, considering that atoms are perfectly inert and have no effect on the accidents that inhere therein. To confirm that the conjunction between an atom and a composite does not engender a causal relation between the accident that inheres in the atom and the composite, al-Juwayni further argues that, considering their inertness, atoms can have no effect on adjacent atoms, and

\footnotetext{
${ }^{121}$ Al-Harrāsī, Ușūl, f. 43b.

${ }^{122}$ Al-Juwaynī, Shāmil, 665-9.

(C) 2012 Hartford Seminary.
} 
that each instance of combination (ijtim $\bar{a}$ ) and composition ( $\left.t a^{\prime} l \bar{i} f\right)$ only affects the individual atom that serves as its substratum. Therefore, since neither atoms themselves nor those accidents that directly account for their composition and aggregation can influence other atoms within a composite body, it would be harder to believe that other accidents could extend their effects beyond the atoms in which they inhere.

A further argument is advanced by al-Juwaynī's students, al-Anșārī and al-Harrāsī: If the perception that occurs in one part of the body is experienced by the composite, then the whole composite - that is, all of its constituent parts - would experience pleasure or pain when instances of pleasure or pain occur in one part of the body. Yet, it is immediately evident to us that "when pain occurs in a certain locus, for instance migraine in the head, we know that no pain occurs in the legs". ${ }^{123}$ Likewise, capacity can exist in one arm, and incapacity in the other arm. To the objection that one finds oneself (nafsa-hu) knowing, and does not detect instances of knowledge in all parts of one's body, al-Anșāri responds that by the same reasoning one does not find each part of his body knowing. In other words, if I, qua composite, have the state ( $h \bar{a} l$ ) of "being knowing", then this state should qualify, and apply equally to, all parts of my body; however, I do not discern, for instance, my arm sharing in my supposed state of being knowing.

\subsection{Man is Not One}

Man, hence, is nothing more than the sum total of his constituent atoms and accidents. As such, he is neither a "thing" nor "one". For, as mentioned earlier, the expressions, "thing" (shay'), or "single thing" (shay" wāhid), and "entity" (dhāt), strictly speaking can be said of simple, indivisible monads, rather than of composite objects. ${ }^{124}$ And in discussing the "reality and meaning of 'one' (ḥaqiqat al-wāhịid wa-maina-hu)", ${ }^{25}$ al-Juwaynī cites al-Bāqillānī defining "one", used as a conventional term (iștilāḥ̂) in religious contexts ( $f \bar{\imath}$ l-diyānāt), as "thing". ${ }^{126}$ This, it appears, is not an arbitrary convention, but is meant to reflect the sense in which God, according to Asharīs, is said to be "one" in the Qur'ān (e.g. 2.163; 5.73; 6.19). Al-Bāqillānī acknowledges that in ordinary language (lugha) this expression is used in a different sense, which, it could be argued, might suggest that "oneness" should not be identified with "thingness" (shay'iyya): for instance, Arabs would describe "man" as "one" (wāḥid), despite being composed of multiple things ( mutarakkib min ashya ). He replies:

When the speakers of the language ( $a b l$ al-lisān) designate the body (shakhss) as "one man", they do so figuratively (tajawwaza). Likewise, they speak figuratively when they designate it ${ }^{127}$ as "one thing". However, if they consider the reality

\footnotetext{
${ }^{123}$ Al-Harrāsī, Ușūl, f. 44a; cf. al-Anșārī, Ghunya, f. 155a; al-Makkī, Nihāya, f. 85a.

${ }^{124}$ See p. 438, above.

125 On the expression "ḅaqiqa", see Frank, Beings and their Attributes, 80-1, n. 5.

${ }^{126}$ Al-Juwaynī, Shāmil, 345-6.

${ }^{127}$ Reading yusammūna-bu, rather than yusammūna.
} 
(tahqiq) of this subject matter, and if the fact that man is divisible and consists of parts becomes evident to them, they will assert that he [comprises] multiple things and individual beings ( huwa ashyä wa-āhạad mawjūdāt). ${ }^{128}$

Since in the strictest sense ( is only one in a figurative sense. For Ibn Fūrak, similarly, the expression "one" (wāḥid), used in the strictest and most formal sense, can only be said of indivisible (ghayr munqasim wa-lā mutajazzi'), incomposite things, such as God, an atom and an instance of the accident black. By contrast, the referent of each of "one man" and "one house" comprises "in reality multiple agglomerated things" ( $f \bar{\imath} l$-ḥaqiqqa ashy $\vec{a}$ mujtami"a). ${ }^{129}$ Al-Juwaynī denies that man is one perceiver, for each atom in which perception occurs is an individual perceiver. ${ }^{130}$ And al-Fazārī contrasts "living" (as a singular adjective or noun), which properly denotes the atom in which life inheres, though it can be applied to the whole composite body only in a figurative and loose sense (majāzan wa-ittisäan), with "man", which properly denotes a composite body. ${ }^{131}$

In the same vein, al-Anșāri considers the objection that it would follow from the Ashara $\overline{1}$ doctrine "that man must be multiple knowing and capable living beings ( $a b y y \vec{a}$ 'älimün qädirūn)", which contradicts the standards of ordinary language. This problem, he replies, arises purely from the conventions of ordinary language. We predicate "a living being" of "man" though he contains numerous instances of life, and "moving" (sg.) of "leg" though each atom therein contains motion. Such applications of "living" and "moving" are only figurative and do not correspond accurately to reality ( haqiqqa), since only atoms can have attributes. ${ }^{132}$ Al-Anșārī suspects that we do not describe an individual man as "knowing and capable living beings" to avoid the suggestion that multiple people are intended. Paraphrasing his teacher's discussion, al-Makkī goes slightly further in his response to the foregoing objection:

What impossibility is there in that [i.e. asserting that man is "knowers"]! Indeed, he is such! However, it is not customary to designate these expressions [to the individual man]. It is, rather, customary to refer to the individual man as "one knower". But he is conventionally one (fard 'urfî), not one in reality (fard ḥaqīi $).{ }^{133}$

\footnotetext{
${ }^{128}$ Cited in al-Juwaynī, Shāmil, 346.

${ }^{129}$ Ibn Fūrak, Mushkil al-ḥadìth, ed. D. Gimaret (Damascus: Institut français d'études arabes de Damas, 2003), 10-11; cf. his student 'Abd al-Karīm al-Qushayrīi, al-Taḥbīrfī l-tadhkīr, ed. I. Basyūnī (Cairo: Dār al-Kātib al-Áabī, 1968), 78.

${ }^{130}$ Al-Juwaynī (Ibn al-Amīr), Ikhtișār, f. 61a.

${ }^{131}$ Al-Fazārī, Sharh al-Irshād, f. 104a. Asháāis typically analogise this with the figurative (majāz) application of "black" (sg.) when said of a man purely on account of the colour of most of the skin, despite the fact that internal parts and some external parts are of a different colour (e.g. al-Baghdādī, Asmā', f. 129b; al-Juwaynī, Shāmil, 669; al-Anșārī, Ghunya, f. 155a; al-Makkī, Nihāya, f. 85b).

${ }^{132}$ Al-Anșārī, Ghunya, f. 155b.

${ }^{133}$ Al-Makkī, Nihāya, f. 86b.

(c) 2012 Hartford Seminary. 
The implication is spelled out unambiguously by al-Makkī's son, the young Fakhr al-Dinn al-Rāzin, who reasons that man is said to be "one" figuratively; for "each atom of man in which life resides is living; man indeed is many living beings (al-insān aḅy $\bar{a}$ kathīün)". ${ }^{134}$

The most detailed extant discussion of the doctrine that man is not a unity and of the problems it gives rise to is found in al-Anșārī's Ghunya, where the author turns seamlessly to the subject following his denial of any intrinsic relationship between accidents and bodily composites (A1 and A2). He introduces his discussion with the following remark directed against the Mutazilī antitheses of A1, A2 and A3:

Asserting that bodily structure [is required] and that a property can belong to it, and affirming its unity (ittiḥa d) is befitting (yaliqu) of those who maintain that the atom is [infinitely] divisible, that only a composite [body] produces acts, that it has the character of a single thing, that the heart is the source of the animal pneuma ( $r u$ t bayawān $\vec{\imath}$ ) and the liver the source of the natural pneuma ( $\left.r \bar{u} b \operatorname{tab} \bar{\imath}^{\prime} \hat{\imath}\right)$, and that organs are connected with each other by nerves and veins and have [in their sum total] the character of a single thing. The Mutazila [by contrast] maintain that the composite [consists of] aggregated monads, but is made as one by composition ( $t a^{\prime} l i f$ ). For [they accept that] knowledge, capacity and life inhere in atoms within the composite; so if they then claim that the properties of these attributes apply to the whole composite, this will be an unsound [position] for them [to take], except in a loose and figurative manner ('alā l-tawassu' wa-l-majāz). ${ }^{135}$

To sustain their claim that man is a unity, the philosophers, hence, can call on two basic theories of theirs. First, their hylomorphism allows them to conceive of the human body, not as an aggregate of discrete monads, but as a single, genuinely-unified substance, which as such could be attributed by a single state that the whole body would, in the strictest sense, be predicated of. Second, they conceive of the body as a unified organism that behaves in an integral manner by the activity of both the animal pneuma that originates in the heart and the natural pneuma that originates in the liver, which are diffused through the body via the nerves and the veins. ${ }^{136}$ Al-Anșārī, like other classical Asharīs, has no sympathy for these philosophical theories, which receive ample criticism elsewhere in his book. To refute the philosophical conception of man as a unity, he would simply address the more basic ontological questions:

If we wish to respond to the exponents of [the theory of] the natures ( $t a b \bar{a}^{\prime} i^{\prime} i y y \bar{u} n$ ), we would begin by offering proofs to affirm both entitative determinants and that a single entitative determinant cannot inhere in two substrata. After that, whoever claims that composites can be living by virtue of an [entitative determinant of] life, we would declare him stupid-minded. ${ }^{137}$

\footnotetext{
${ }^{134}$ Al-Rāzī, Ușūl, f. 43a.

${ }^{135}$ Al-Anșārī, Ghunya, f. 154b.

${ }^{136}$ In the Galenic tradition, the animal, or "vital", pneuma is in fact diffused via the arteries. The nerves distribute the psychic pneuma, which al-Anșārī does not mention here.

${ }^{137}$ Al-Anșārī, Ghunya, f. 155a.
} 
Al-Anșārī merely intends to point out that as far as the unity of man is concerned, the philosophers exhibit greater consistency in espousing this notion than do the Mutazila. The atomist ontology that both they and the Asharīs share, in his assessment, does not allow for such a conception.

The comparison with the philosophers (the so-called taba ${ }^{\prime} i^{\prime} i y y u m$, exponents of the theory of the four natures) is pursued a little further to highlight another inconsistency in the Mutazili position. In accordance with their premise that bodily structure is a condition for attributes (he actually writes, "entitative determinants" [ma $\bar{a} n \bar{\imath}]$ ) specific to animate beings, the philosophers maintain that bodily structure must be a condition for their properties, and hence do not affirm these properties for God. The Mutazila, by contrast, contradict ( $n \bar{a} q a d a$ ) their own principle that life requires structure and affirm the animate being's attributes for God. This criticism appears to have been advanced earlier by al-Juwaynī. ${ }^{138}$

Al-Anșārī then turns his attention to several problems and objections, to be discussed next, provoked by the denial of the possibility of any ontologically real property $(\mathrm{hukm})$ for the human body as a whole that would engender unity within man. Some problems begin from either the religious and ethical status of the individual: whether the obligated agent ( mukallaf) is the whole of the composite body, or only a part thereof. ${ }^{139}$ Others begin from our knowledge of the normal workings of the animate being's attributes, which we have as human beings: whether or not the different "occurrences" observable within man and experienced in different bodily loci are actually experienced by one and the same entity, be that a psychological core component within the body, or the whole of the body as a unity.

Problem 1. Belief and knowledge. The most primary, cognitive obligation on man, to have belief ( $\bar{i} m \bar{a} n$ ) and theological knowledge ( $m a \dot{r}$ ifa), is normally the first and main case in point discussed. Al-Bāqillānī and al-Anșārī describe two configurations that they regard conceivable. In the first, the accident of knowledge inheres only in the atoms of the heart. We know that knowledge is located in the heart, according to al-Bāqillānī, by the consensus of the Muslim community, whereas for al-Anșārī this is attested unequivocally in the Qur'ān and some hadīths. ${ }^{140}$ Each cardiac atom that serves as the substratum (mahall) of knowledge, to the exclusion of all other atoms of the body, would be a believer ( mu'min mușaddiq) and commanded (ma'mür) to believe. The whole composite may also be designated "a believer", "a knower" or "an unbeliever",

\footnotetext{
${ }^{138}$ Al-Juwaynī, Shāmil, 668. He refers us to the "chapter on man and spirit", which he probably never wrote (see p. 436 above).

${ }^{139}$ Al-Fazārī, Sharh al-Irshād, ff. 104a; $104 \mathrm{~b}$ (in the margin, where a passage discussing this question is cited from al-Bāqillānī's Hidāya). Al-Juwaynī ([Ibn al-Amīr], Ikhtiṣār , f. 224b), hence, lists the reality of man and the spirit among the subtopics of the major subject of the nature of good, evil, justice and injustice (al-taidìl wa-l-tajwìr).

${ }^{140}$ Al-Anșārī, Ghunya, ff. 155a; 155b; cf. al-Makkī, Nihāya, ff. 85b-86a; al-Fazārī, Sharḥ al-Irshād, f. $104 \mathrm{~b}$ (margin). On the locus of knowledge, see also p. 449 above.
} 
but only as a concession either out of piety and obedience to the Lawgiver (min jihat al-din wa-l-taiabbud min al-shäri), who assigns (tawqiff) the expression "believer" to the whole composite even in cases in which the referent is not properly a believer (for instance, during sleep or unconsciousness, when the accident of belief is absent from the entire body), or in accordance with standard figures of speech used in ordinary language (lugha), as has already been explained. Al-Makkī writes:

Had revelation not stipulated that the composite ought to be designated a "believer", only that atom [that contains belief] would be designated a "believer"; but since revelation designated the expression "believer" to the totality, we unhesitantly say that [the composite] is a believer. ${ }^{141}$

On whether the composite can be a "believer" while asleep, he writes: "His being a believer is a religious judgement ( stipulates that [the composite] is a believer; therefore, he is a believer". ${ }^{142}$

In this configuration, al-Anșārī explains, non-believing atoms in bodily parts other than the heart cannot be deemed disbelieving ( $k a \bar{a} f i r$ ), since they are not commanded to believe. Their presence should not contradict the designation of the whole composite as a "believer", for two reasons. First, the Lawgiver has stipulated that the same religious status ( $\mathrm{hukm}$ ) that the believing atoms in the heart have should apply to the whole body, including non-believing atoms. Second, the other parts of the body have been made subservient (sakhkhara) to the heart, which thus uses (istakhdama) them in accordance with its knowledge and motives. ${ }^{143}$ Though not a unity, the body, hence, is not a disunity.

In the second proposed configuration, which according to al-Anșāri is suggested in some hadīths, the accident of belief will inhere in all the atoms of the composite, which, qua the sum total of its parts, may then be designated wholly, and hence literally, "believing". From the greater attention that the former configuration is afforded by both al-Bāqillānī and al-Anșārī, it appears that this is their preferred model; and indeed it accords with the widely-current notion that knowledge and belief occur in the heart, not throughout the body. ${ }^{144}$

Problem 2. Can the whole be rewarded or punished for the acts of the part? Contra the Mutazila, according to whose ethical realism it would be unjust to punish an atom for an evil act committed by another atom, the Asharīs have no ethical qualms to

\footnotetext{
${ }^{141}$ Al-Makkī, Nihāya, f. 85b.

${ }^{142}$ Al-Makkī, Nihāya, f. 86a.

${ }^{143}$ Al-Anșārī, Ghunya, f. 155b; cf. al-Makkī, Nihāya, f. 86a; Ibn Fūrak, Mujarrad, 146; al-Juwaynī, Niz̄āmiyya, 246-7.

${ }^{144}$ Al-Ashárī (Ibn Fūrak, Mujarrad, 146; cf. al-Baghdādī, Asmā', f. 130a) maintains that though it is rationally conceivable (lā yastahìilu ... nazaran wa-'aqlan) for the same composite to contain believing atoms, which are rewarded in heaven, and disbelieving ( $k \bar{a} f i r)$ atoms, which are punished in hell, all Muslims are unanimous on the inconceivability of this. For al-Makkī (Nihāya, f. 85b), although the occurrence of such cases is rationally conceivable, it is contrary to the normal course of events ('âda).
} 
pronounce that only parts of the body are properly believing or unbelieving. To the objection, "How does the composite deserve reward or punishment for the belief or unbelief that exists in the part?", al-Anșārī hence responds, in keeping with the standard anti-realist voluntarism advocated in classical Asharism, that no one deserves (istahaqqa) anything, be it reward, compensation or retribution, from God, which He then is obligated to deliver. ${ }^{145}$ The existence of belief in an atom in the heart does not bestow it with any desert of reward, but only represents a sign ('alam) for both the reward that the whole composite will receive in the hereafter and the religious obligation (wujūb) on other believers to praise the composite as a whole, just as the Lawgiver stipulates the tongue's profession (iqrār) of belief as a sign ('alāma) for the applicability of certain legal rulings (bukm) to the whole composite. ${ }^{146}$

Problem 3. Can one part be rewarded or punished for the acts of another part? The same voluntarist reasoning applied to cognitive religious obligations rewarded or punished in the hereafter is invoked to explain punishments ( $h u d \bar{u} d$ ) stipulated for offences of the limbs and dispensed while the person is alive. The problem is that in most cases one part of the body is punished for an offence committed by another part: How, it is asked, could the back be flogged for the fornication committed by the sexual organ or the false accusation of fornication ( $q a d h f$ ) committed by the tongue, the neck be chopped for the unbelief of the heart or the tongue (in the case of apostasy), and the right hand be chopped for a theft committed by the left hand? Al-Anșāri explains that committing an offence such as these is only a sign that indicates ('alam däll) that it is obligatory on others to dispense the stipulated punishment, and that God indeed is entitled to forgive grave offences, for instance when the offender repents, and to inflict retribution even if no limbs have acquired (iktisāb) any offences. An example of the latter is that He permitted the enslavement of children for the unbelief committed by their parents. ${ }^{147}$ Al-Anșārī then argues that the same argument can be turned against the Mutazila, who claim that the composite, rather than the hand or the sexual organ, is the true agent that commits theft and fornication, respectively. Nonetheless, they accept that punishment should be meted out against other organs and that repentance ought to be performed by the heart, though neither committed the offence. This, he objects, would be "thoroughly unjust" (zulm maḥd) according to the Mu'tazilī theory of justice. ${ }^{148}$

\footnotetext{
145 Therefore, God is under no obligations and has discretion to reward or punish as He wishes (though His promise to reward good-doers and punish evil-doers must be trusted). On the theological voluntarism of classical Ashárīs, see: Shihadeh, Teleological Ethics, 49 ff.; Richard Frank, "Moral Obligation in Classical Muslim Theology," Journal of Religious Ethics 11 (1983): 204-23; George Hourani, "Juwaynī's Criticisms of Mutazilite Ethics," Muslim World 65 (1975): 161-73.

${ }^{146}$ Al-Anșārī, Ghunya, f. 155a; cf. al-Makkī, Nihāya, f. 85b.

${ }^{147}$ Al-Anșārī, Ghunya, f. 155a.

${ }^{148}$ Cf. Ibn Fūrak, Mujarrad, 217, where al-Ashárī reproduces a similar argument from earlier Mu tazilī sources (on which see p. 454 above). On Mutazilī discussions surrounding this problem, see: Sophia 
Problem 4. How could an occurrence in one part lead to an act in another part? It is argued that had the seeing thing (mubsir) been the substratum of the accident of sight, then only the organ of sight would be responsible for the act of avoiding a hazard (say, a well) it detects along the person's path. ${ }^{149}$ Al-Anșārī replies that the composite avoids the hazard by virtue of the knowledge ( $\mathrm{ilm}$ ) it has of the visual perception in the eye, which "makes the composite equivalent (musāwi) to the substratum of sight". ${ }^{150}$ Two configurations are conceivable: either knowledge and will are present in each act-producing atom ( $j u z^{\prime} f a^{\prime \prime} \overline{a l}$ ) in the body, such as those of the legs that avoid the hazard, or they are present in the heart, though the act is performed by other bodily organs, which are subservient to it.

Problem 5. Could different parts of the body act disharmoniously? From the foregoing notion that will could exist in the act-producing atoms, another problem follows. Could one leg will (turid) to go in one direction, and the other leg in another direction? Al-Anșārī's reply is uncompromising: "The mind does not judge it impossible; yet the normal course of events assures us against its occurrence (al-'áda ämanat-nā min-bu)" ${ }^{151}$ In the hereafter, the normal course of events will be altered, such that the tongue turns mute and the limbs bear witness and speak, as depicted in the Qur'ān (36.65; 41.20).

Problem 6. Perception, knowledge and speech. The problem is postulated as follows. ${ }^{152}$ If Zayd hears speech, which his heart then understands, and if the tongue then responds to the speech heard, will the responder be the tongue, the heart or the hearer (sāmi, i.e. the ear)? Al-Anșārī replies by appealing to the Asharầ doctrine of pre-verbal inner speech, and argues that the true responder is the speaking atom (juz' mutakallim) in the heart, which acts as a substratum for speech: the tongue merely reproduces this inner speech in audible form. By doing so, the tongue obeys the normal course of events preserved by God, in which some bodily organs are made subservient to others. "God maintains His custom (sunna)", al-Makkī writes, "such that some organs are subservient (musakhkhara) to others, and all [organs] are subservient to the heart". However, al-Anșārī considers it conceivable for the tongue to contain knowledge and perception (idrāk) of the speech heard (apparently a reproduction of the auditory perception in the ear), alongside sound, motion and capacity, though such perception would be called "hearing" only when it occurs in

Vasalou, Moral Agents and Their Deserts. The Character of Mutazilite Ethics (Princeton and Oxford: Princeton University Press, 2008).

${ }^{149}$ Al-Anșārī, Ghunya, f. 155b.

${ }^{150}$ Cf. p. 449 above.

${ }^{151}$ Al-Anșārī, Ghunya, f. 155b; cf. the brief summary in al-Makkī, Nihāya, f. 86b.

${ }^{152}$ Al-Anșārī, Ghunya, f. 155b; cf. the brief summary in al-Makkī, Nihāya, f. 86b. 
the ear. ${ }^{153}$ In that case, it seems, the tongue would be, at once, the hearer, the knower and the speaker. ${ }^{154}$

\section{The Spirit (rūug)}

That, thus far, there has been hardly any mention of the spirit is simply a reflection of the rather vague and marginal role it is assigned in classical Ashari anthropology. From the point of view of Asharī ontology, the need to stipulate a human soul or spirit did not arise. All human attributes and activities are explained by a range of accidents that inhere in the atoms of the bodily composite, including knowledge, thinking, will and perception. At every moment, each accident is recreated or replaced with a different accident by God, who may even choose to annihilate the whole world, including atoms, and to recreate it before humans are resurrected. So when the body of Zayd dies and loses all its animate attributes, God can simply duplicate these attributes when He "restores" ( $\left.a^{\prime} \bar{a} d a\right)$ Zayd, including his religious beliefs, memories of his previous life and all other items of knowledge he had before he died. A spirit would be entirely redundant.

Nonetheless, the Qur'ān and Hadīth contain frequent and often vivid depictions of the "rüh" and "nafs" of individual human beings. ${ }^{155}$ And it is only to account for these scriptural depictions, rather than to explain any properties of man that remained unaccounted for by the standard means of accidents, that classical Asharins discuss the "spirit". Often, however, theologians admitted that their interpretive attempts and proposed conceptions of the spirit were nothing but speculative guesswork and fell below the standards of certainty required in the core parts of theology. As evidence that humans cannot know the spirit's nature with certainty, some adduce Q. 17.85, "They question you concerning the spirit. Say: The spirit is of my Lord's domain. You have been given of knowledge nothing except a little". ${ }^{156}$

If humans, individually, have something called "spirit", (and all classical Asharīs, we are told, employed "rūth" and "nafs", in the sense of "individual spirit", interchange-

\footnotetext{
${ }^{153}$ According to al-Juwaynī (Ibn al-Amīr, Ikhtișār, ff. 134a-b), an atom capable of perception is capable of all types of perception. Moses, hence, is said to have heard God's speech in all his body, not just his ears.

${ }^{154}$ A seventh problem that al-Anșārī addresses has already been discussed earlier in the present section (p. 459).

155 As both expressions are considered homonyms (ism mushtarak), theologians attempt to isolate this sense from occurrences in which they are used in different, irrelevant senses, for instance "the Qur'ān" (Q. 42.52) or "mercy" (58.2) in the case of rüh, and "the thing itself" (dhāt) (3.28) or "the body" (2.54) in the case of nafs (for instance, al-Anșārī, Ghunya, f. 217b; al-Fazārī, Sharh al-Irshād, ff. 101b-102a; al-Rāzī, Ușūl, ff. 179b-180a; al-Bayhaqī, al-Asmā' wa-l-șifāt, ed. 'A. al-Hāshidī, 2 vols. [Jeddah: Maktabat al-Sawādī, 1993], 2, 48 ff.; 210 ff. For an overview of occurrences in the Qur'ān, see: "Soul"; "Spirit," Encyclopaedia of the Qur'ān).

${ }^{156}$ For instance, al-Anșārī, Ghunya, f. 218a. Al-Fazārī (Sharḥ al-Irshād, f. 101b) writes, "We cannot be certain of what it is". 
ably), ${ }^{157}$ the most primary question that the sources then ask is whether it is a body ( $\left.j i s m\right)$, i.e. a collection of atoms, or an accident. Most sources will also point out that there is much disagreement (khiläf) among earlier school authorities on this matter. The following positions are attested:

1. "Spirit" refers to the accident of life: a position probably taught by al-Qalānisī. ${ }^{158}$

2. "Spirit" refers to the breath: the position of al-Ash'arī and Ibn Fūrak.

3. "Spirit" has two senses, namely life and breath: the position of al-Bāqillānī and, following him, Abū Ishạa al-Isfarā'īnī (d. 418/1027). ${ }^{159}$

4. "Spirit" refers to a subtle body embedded within the human body: the position taught by al-Juwayn̄̄.

No classical Asharīi, it seems, ever proposed that the spirit was an accident other than life. Though some of these strands appear to have existed concurrently in classical Asharism, the strand that associates the spirit with the breath, taught by the school founder and al-Bāqillānī, may have been in vogue during the 4th/10th-century and the early 5th/11th-century. Ibn Hazm (d. 456/1064), hence, attributes this position to the Asharīs in general. ${ }^{160}$ The last strand appears to gain prominence in the late-5th/11th and early-6th/12th centuries, after it was endorsed by al-Juwaynī. There are also those who simply affirm that the spirit is a body, but seem to elaborate no further, the chief example being al-Baghdādī. ${ }^{161}$ In what follows we shall examine these two strands in turn, before considering the slightly later trend that, around the turn of the 6th/12th century, cast doubt on both strands.

\section{i. Al-Ashiari}

Ibn Fūrak reports that al-Asharin maintained that the spirit is that subtle body ( $j i s m$ latîf) - i.e. a body comprised of sparsely-dispersed atoms, in contrast to densely-compacted bodies (jism kathif ) — that goes in and out of the cavities of the

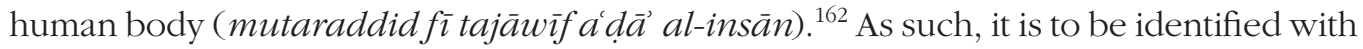
wind ( $r i \bar{b}$ ), which is simply air particles ( haw $\bar{a}$ ) in which motion ( haraka) occurs: when air moves in a specific manner ('alā wajh makhșüs) through the breathing orifices ( makhärīq), in and out of bodily cavities, and in the presence of life within the body, this

${ }^{157}$ Al-Fazārī, Sharḥ al-Irshād, f. 102a; cf. the Māturīdī al-Ṣaffār, Talkhīṣ al-adilla, 1, 254. "Rūḥ", however, was the more prevalent term in kalām.

${ }^{158}$ Al-Fazārī, Sharḥ al-Irshād, f. 101b. Though, of course, not an Ashárī, al-Qalānisī is often considered by Asharīs to be one of their "imāms".

159 Al-Anșārī, Ghunya, f. 217a; al-Fazārī, Sharh al-Irshād, f. 101b.

${ }^{160} \mathrm{Ibn}$ Hazm, al-Fișal fì l-milal wa-l-ahwä wa-l-niḥal, 5 vols. (Cairo: Maṭa'bat al-Tamaddun, $1321 \mathrm{AH}$ ), 4, 69; cf. 5, 74; 76.

${ }^{161}$ For instance, al-Baghdādī, Ușūl, 105; idem., Asmā̄, f. 205b. The same position finds expression in the more traditionalist Asháāi sources, including al-Khațābī and al-Bayhaqī (see the latter's al-Asmä wa-l-șifät, 2, 213).

${ }^{162}$ Ibn Fūrak, Mujarrad, 257; cf. Gimaret, La doctrine d'al-Ash'arī, 70-2; 127-8. According to al-Anșārī (Ghunya, f. 217a), the same conception of the soul is held, unsurprisingly, by Ibn Fūrak himself: the spirit "is that which flows through the cavities of the organs (tajāwîf al-a'dä́)". 
flowing air will be called "spirit" (rūhp). ${ }^{163}$ As such, the spirit's relation to the body will be one of adjacency (mujāwara), rather than interpenetration. ${ }^{164}$ It is conceivable that the atoms of the spirit be either living, by the inherence of the accident of life in them, or inanimate. ${ }^{165}$ As evidence of the soul being a body, rather than an accident, al-Asharā reportedly cites the standard expression, "the spirit departed (kharaja)", and the Qur'ānic verse, "When it [the spirit] reaches the throat" (56.83), both of which indicate that the spirit can move in space: a feature that distinguishes atoms from accidents. ${ }^{166}$

Al-Fazārī remarks convincingly that by equating "rū ḥ" with "rīḥ" al-Asharāi interpreted relevant Qur'ānic occurrences of the former expression in what he considered a literal sense: he tended "to preserve the prima facie senses (zawābir)" of Qur'ānic expressions and "refrained from interpreting them figuratively ( $\left.t a^{\prime} w i \bar{l}\right)$ as long as they yielded [meaning] (ifāda)". ${ }^{167}$ Literal interpretation was the preferred, default option. Figurative interpretation was, in principle, only resorted to when a literal interpretation of an expression rendered the sentence in which it occurred unintelligible or, more pressingly, when it entailed an impossible consequence (as in the foregoing case of Qur'ānic references to the individual man as "a believer" or "an unbeliever", and passages that suggest that God has a location in space). Neither consequence was seen to arise from the supposedly-literal interpretation of "rūh" as "flowing air", or "wind".

Al-Ashari reportedly compares the presence of the breath-spirit in the body to that of nourishment ( ghidh $\vec{a})$ :

The body is normally sustained (qiwām) by the spirit, just as it is sustained by nourishment, food and drink. For it is inconceivable (la yașị̣ḥu) that it live in the absence $(f a q d)$ of nourishment or in the absence of the spirit. For the living being, to be living, needs (iḥtāja) spirit and nourishment; and the "condition" (shart) of the existence of life is the existence of spirit and nourishment. ${ }^{168}$

Although we are not told exactly how the spirit is a vital component of the living being, the language used to characterise its relation to the body in this passage indicates that it is treated as a "condition" (shart, mușạ̣hịh), or almost as a cause ('illa), much in the same way that the accident of life is a condition for the existence of the other animate being's attributes. As we shall see shortly, this position is untenable.

\footnotetext{
${ }^{163}$ Ibn Fūrak, Mujarrad, 271. Though the identification of the spirit with the breath was ubiquitous, al-Ashárī's definition and treatment exhibit a direct Mu'tazilī influence (cf. 'Abd al-Jabbār, Mughnī, 11, 336; 338; Gimaret, La doctrine d'al-Ash'arī, 127; Heemskerk, "Abd al-Jabbār," 133-6; Peters, God's Created Speech, 164-5; on the association made between spirit and breath, and other conceptions of the soul advanced in earlier Mutazilism, see van Ess, Theologie und Gesellschaft, 4, 513 ff., esp. 515).

${ }^{164}$ Al-Fazārī, Sharh al-Irshād, f. 102a.

${ }^{165}$ Ibn Fūrak, Mujarrad, 257 (ln. 18, reading mawāt instead of mawt); also in al-Fazārī, Sharh al-Irshād, f. $102 \mathrm{a}$.

${ }^{166}$ Ibn Fūrak, Mujarrad, 257; cf. Gimaret, La doctrine d'al-Ash'arī, 127.

${ }_{167}$ Al-Fazārī, Sharh al-Irshād, f. 102a.

${ }^{168}$ Ibn Fūrak, Mujarrad, 257; also in al-Fazārī, Sharh al-Irshād, f. 102a.

(C) 2012 Hartford Seminary 


\section{ii. Al-Bāqillānī}

The association between spirit and breath is preserved by al-Bāqillānī, who is said to have proposed two definitions for the expression "rü something that exists within the human body. In one set of occurrences, it refers (as reported by al-Anșārī) to breath (nafas), which is "flowing air that gets diffused (rīḥ munbasit)"; or (as clarified by al-Anșārī's student al-Makkī) it is "flowing air that gets diffused within the breather (yanbasitu 'alā l-mutanaffis)". ${ }^{169}$ In other words, it is further explained, "spirit" denotes "the atoms of the air $(a j z \vec{a}$ al-haw $\vec{a})$ that enter into the breathing orifices", which "are inhaled cold and exhaled warm".

In the Hidāya, al-Bāqillānī offers several arguments to illustrate that life should not be identified with the spirit (in other words, that a thing becomes living by the entitative determinant of life, not by the presence of the breath), including the following three. ${ }^{170}$ First, if life is identified as spirit, all living beings would be described as "spiritual" (rüḥāni); however, God is living, but is never given this attribute. ${ }^{171}$ Second, we know that life exists in non-hollow (musmat) parts of the body in which there are no gaps ( $k$ halal) or cavities (farägh); its substratum, hence, is living but contains neither cold nor hot flowing air. By the same reasoning, if it is affirmed that the substratum of life perceives pain, pleasure, heat or coldness because it is living, then non-hollow parts of the body would be incapable of any of these perceptions. The last two points confirm that the spirit gets diffused only within bodily cavities. The choice of the verb "inbasata", which mainly implies spreading on a surface, may be intended to limit the extent of the diffusion of the breath-spirit to the inner surfaces of bodily cavities. ${ }^{172}$

In other occurrences, "rīḥ" denotes the accident of life. Though the extant sources shed extremely little light on this view, it seems that al-Bāqillānī may have felt that the reductive identification of "rü existence of a constant individual human spirit, at least in the sense that, critics argue, is implied in numerous Qur'ānic verses and hadîths: one that can be predicated of

169 Al-Anșārī, Ghunya, f. 217a; al-Makkī, Nihāya, f. 87b; al-Rāzī, Ușūl, f. 178b. Ibn Hazm reports (Fișal, 5, 74) that al-Bāqillānī designated life as "nafs", and breath as "rū ḥ", a distinction not mentioned in extant classical Ashárī sources.

${ }^{170}$ Cited in al-Fazārī, Sharh al-Irshād, f. 102b (margin). The marginal note goes on to cite a further, mostly illegible discussion from the Hidāya, which seems to argue that the spirit is a body and should not be identified with the accident of life.

${ }^{171}$ This, of course, seems to clash with al-Bāqillānī's aforementioned view that "rūṭ", in some occurrences, can denote "life". He might have held that the latter sense can only be intended when certain conditions are fulfilled; however, the sources available shed no light on this. On the expression "rūḥān $\vec{\imath}$ " and its inapplicability to God, see: Ibn Fūrak, Mujarrad, 44; 281 (jinn and angels are called "rūḥāniyyūn" only because their bodies are akin, in their subtlety, to air); al-Baghdādī, Ușūl, 105; idem., Asmä, ff. 124a; 125a; 255a; idem., Farq, 325.

${ }^{172}$ A note in the margin of al-Fazārì's Sharh al-Irshād (f. 101b) seems to confirm this sense. It cites the lexicographers' opinion that the original sense of "rawh" is "inbisāt", and supports that with the expressions "qadam rawh $\vec{a}$ ", "a foot spreading (munbasit) in its fore part", and "arwah", one who has such feet (cf. Edward Lane, An Arabic-English Lexicon [London: Williams and Norgate, 1863-1893], 1183). 
attributes (mawsüf), can survive the death of the body, and can be transported in space. ${ }^{173}$ As Ibn Hazm remarks in his criticism of the Asharī conception of the spirit, it would be absurd to claim that the air inhaled and exhaled, which changes with every breath, could be a component of the individual human being that survives the death of the body. ${ }^{174}$

The difficulty is overcome by the second definition of "rū ḥ" that al-Bāqillānī offers. This develops an earlier notion used by al-Ashari to account for reports concerning the inquisition and torment in the grave, namely that God can create life and perception in some of the atoms of the deceased person's body. ${ }^{175}$ Al-Ashari $\overline{1}$, however, apparently never refers to this accident of life as "spirit". It is possible, the school founder asserts, "that God, exalted, create life in the atoms in which He had created death, [i.e. the atoms of Zayd's body,] and then cause them pain by creating instances of pain in them". It is the atoms of Zayd's body that are meant to be tormented; life and perception are created only to allow this torment to occur. Neither atom nor life, in this case, could aptly be designated "spirit", considering that scriptural occurrences of this expression are not confined to references to the inquisition and torment in the grave.

Crucial developments can be detected in al-Bāqillānī's position, gleaned from the exiguous accounts available in later sources. To account for hadiths that affirm the posthumous survival of "the spirits of martyrs and the spirits of the family of Pharaoh", he suggests, according to Ibn Hazm, that if the "spirit" is identified with life, it may survive death: "Either the accident of life becomes seated (yüda'u) in the most minute part of the body", that is, in a fragment of the original body, even one as small as an atom. "Or another body is created for that life (li-tilka l-hayät)", for instance the body of a bird. ${ }^{176}$ The choice of words used in Ibn Hazm's direct quotations is peculiar, especially when compared to al-Asharī's much simpler, "God creates life in the atoms". Both "seated" (or "placed") and "for that life" suggest that the life in question is the same as ${ }^{177}$ the life that existed in the body at the moment of death, as though it is transferred to a new substratum. The original substratum becomes secondary and dispensable, as the individual's life can be reproduced in a substitute body. Moreover, the continuance of life seems uninterrupted in al-Bāqillānī's account, whereas al-Ash'arī implies that life is only created just as the inquisition and torment commence.

\footnotetext{
${ }^{173}$ For instance, al-Fazārī, Sharḥ al-Irshād, f. 102b; al-Ṣaffār, Talkhīṣ al-adilla, 1, 255-6.

${ }^{174}$ Ibn Hazm, Fiṣal, 5, 76-7.

${ }^{175}$ Ibn Fūrak, Mujarrad, 170-1.

${ }^{176}$ Ibn Hazm, Fișal, 5, 77. On "bird traditions" that state, for instance, that the spirits of martyrs will dwell in green birds and that those of the family of Pharaoh in black birds, see: van Ess, Theologie und Gesellschaft, 4, 523-5; Ragnar Eklund, Life Between Death and Resurrection According to Islam (Uppsala: Almqvist \& Wiksells, 1941), 16-20.

177 That is, inasmuch as Zayd's life and knowledge at any given instant are the "same" as his life and knowledge in the previous moment. In classical Ashárī occasionalism, an accident subsists for no more than an instant and must be recreated or replaced with a different accident at each instant.
} 
This is certainly how Ibn Hazm understood al-Bāqillānī: not only from the snippets he reproduced, but from the complete text he had at his disposal. For he objects that "an accident cannot be taken back (tuwuffiya), such that it departs from ( färaqa) the body that bears it, and then continues to exist (baqiya) in that state". This is "inconceivable; for the accident ceases to exist when it departs from its substratum". ${ }^{178}$ Ibn Hazm then condemns the notion that life (the spirit) can be reproduced (nusikha) in another body, such as the body of a bird, on the grounds that it amounts to metempsychosis (tanāsukh) straight and simple. ${ }^{179}$

The significance of the posthumous survival of the accident of life lies in that it allows its substratum to receive the other animate attributes of the individual, which, as explained earlier, are conditional upon life. According to al-Fazārī, those who equate "rūh" with life defend this position against the objection that the "entity predicated of attributes" (mawșüf), depicted in various Qur'ānic verses and hadīths, cannot be the accident of life itself; for one accident cannot be qualified by another. They respond that the entity in question is not life itself, but rather the atom in which life inheres. ${ }^{180}$ This most probably was a point made by al-Bāqillānī, the main figure to whom al-Fazārī earlier ascribes the definition of "spirit" as "life" and to whose Hidāya he had access. The endurance of those attributes that encapsulate the individual's identity, including potentially all items of knowledge, hence allows for the possibility of an uninterrupted survival of the individual beyond the death of the body. What endures of Zayd and 'Amr, if anything does endure, is not only the life that each of them has, but furthermore, for instance, their belief or unbelief, memories, acquisitions, desert of reward or punishment, and perception of the happenings and experiences, described in scripture, which the spirit goes through in the period between the death of the body and resurrection. This, to my mind, underpins al-Bāqillānī's identification of the spirit with life. Whether he believed that the spirits of all human beings survived the death of the body, or confined that to those of the aforementioned privileged or damned classes mentioned expressly in the Hadith, is unclear. ${ }^{181}$ Either way, he appears to be the first to offer this explanation for the possibility of the posthumous survival of the spirit.

\section{ii. Al-Juwaynì and al-Qushayrī}

The identification of the "spirit" as either breath or life was influential in late-fourth/ tenth- and early-fifth/eleventh-century Asharism: it was taken on board by al-Bāqillānī's

\footnotetext{
${ }^{178}$ Ibn Hazm, Fiṣal, 5, 76.

${ }^{179}$ Ibn Hazm, Fișal, 5, 77.

${ }^{180}$ Al-Fazārī (Sharḥ al-Irshād, f. 102b) reports this response, but rejects it in favour of al-Juwaynī's conception of the spirit.

${ }^{181}$ According to a citation in al-Anșārī's Sharḥ al-Irshād (MS Aya Sofia, f. 269a), al-Bāqillānī interpreted "Allāh yatawaffā al-anfus" (Q. 39.42), not as "God takes back the souls", but as meaning that God "creates life in man until he reaches his appointed time (ajal)"; when this appointed time arrives, God "omits to create life; so he dies". This suggests that the individual's animate attributes would cease to exist and disappear at the moment of death, and consequently that only some human spirits survive death. 
"followers", ${ }^{182}$ as well as Abū Ishāq al-Isfarā'īnī. An alternative theory of the soul, however, already had some following within the school, although the identity of its exponents among fourth/tenth-century Asharīs remains unclear. This disagreement within the school is reported by al-Qushayrī in the Risāla, which he completed in 438/1046. He writes in the section on the spirit (rüho):

The "spirits" are subject to disagreement among the critical investigators of the Sunnis. Some assert that it is life. Some assert that it refers to entities (a'yān) that are seeded ( $m \bar{u} d a)$ in these bodily structures ( $q \bar{a} l i b)$, which are subtle (lațîf), and that God sustains the normal course of events (' $\bar{a} d a$ ) by creating life in the structure as long as the spirit exists in its body. Man, hence, is living on account of the [accident of] life. The spirits, [by contrast,] are seeded in the structures. [. . .] The traditions $(a k b b \bar{a} r)$ confirm that ["spirit"] denotes subtle entities. ${ }^{183}$

The expression "a'yā $n$ " here means "body" or "atoms", as opposed to accidents. ${ }^{184}$ In the previous section, on the "ego" ( $n a f s$ ), he writes that the spirit is a "body of subtle form" ( min al-ajsām al-lațîfa fì l-șūra), just as angels and demons have subtle bodies. ${ }^{185}$ As explained earlier, "subtle body" simply means "a sparsely-dispersed body". Beyond this basic identification of the spirit as a subtle body within the visible human body, al-Qushayrî's anthropology has predominantly-Sufi concerns, which deserve a separate treatment.

The theory that the spirit is a subtle body gained prominence slightly later when it was endorsed by al-Juwaynī, who writes in the Irshäd:

If it is said, "Explain the 'spirit' and its reality (ma'nā); for there has been disagreement on this". We say: The soundest position (al-az̧har), in our view, is that the spirit consists of subtle bodies intermingled with the sensible bodies (ajsām lațîfa mushābika li-l-ajsām al-maḥsūsa). God, exalted, sustains the normal course of events (' $\bar{a} d a$ ) such that the life of [the sensible] body continues (istimrār) as long as [these subtle bodies] continue (istamarra) to be intermingled with them. If they depart (färaqa) from them, death, in the normal course of events, will succeed life. ${ }^{186}$

After death, the spirit is transported, following some hadiths, in the crops of green birds to be deposited into heaven or hell. ${ }^{187}$ In contrast to the breath-spirit of earlier Asharīs, al-Juwaynī's spirit is not identified with breath and does not flow through orifices and

${ }^{182}$ As confirmed by Ibn Hazm (Fișal, 5, 76) and al-Fazārī (Sharḥ al-Irshād, f. 102b).

${ }^{183}$ Al-Qushayrī, Risāla, 1, 205.

${ }^{184}$ Cf. Abū l-Mu'īn al-Nasafī, Tabșirat al-adilla, ed. C. Salamé, 2 vols. (Damascus: Institut français de Damas, 1990), 1, $44 \mathrm{ff} .$, where "áyān" is used in the same sense.

${ }^{185}$ Al-Qushayrī, Risāla, 1, 204.

${ }^{186}$ Al-Juwaynī, Irshāe, 377.

${ }^{187}$ Al-Juwaynī, Irshād, 377. Al-Nažām is reported to have identified the spirit as life intermingled ( $m u s h a \bar{a} b i k$ ) with the body; but his physical theory was very different from that of classical Asharism (see 'Abd al-Jabbār, Mughnī, 11, 310; al-Baghdādī, Farq, 117; van Ess, Theologie und Gesellschaft, 3, 309 ff.). 
into bodily cavities, but is intermingled with the body, including its non-hollow parts. Unlike flowing air, which can be sensed on account of its motion and temperature, this subtle body seems to be insensible: hence the contrast with the "sensible" bodies with which the spirit is intermingled. ${ }^{188}$ Al-Juwayni agrees with his predecessors that the atoms of the spirit can conceivably be either living by the inherence of the accident of life in them, or inanimate. ${ }^{189}$

How exactly the spirit is intermingled with the body, al-Juwayni does not explain here. After all, two composite bodies, as he argues in the Shämil, cannot interpenetrate each other (tadākhul) and hence cannot be co-located. ${ }^{190}$ Yet this physical principle does not apply to subtle bodies, an example being the jinn who, according to al-Juwaynī, indeed can interpenetrate (däkhala) human bodies. ${ }^{191}$ In discussing how an angel can penetrate the earth to reach a buried corpse and conduct the inquisition in the grave, the young Fakhr al-Dīn al-Rāzì explains that this does not imply the co-location and interpenetration of bodies, which would be inconceivable. Rather, since angels are subtle bodies, "it is conceivable that they penetrate in the gaps among the atoms of the earth, just like water seeps into" the ground. We also know, he adds, that angels visit us day and night without being obstructed by the walls that surround us. ${ }^{192}$ This undoubtedly reflects al-Juwaynī's understanding of the manner in which the spirit is intermingled with the body. Embedded in the human body, the atoms of the spirit have a special, yet unexplained, status, which makes them distinct from, say, the atoms of the flesh. ${ }^{193}$

Although, like al-Asháarī's and al-Bāqillānī's breath-spirit, al-Qushayrī's and al-Juwaynî's bodily spirit is concomitant with life, there appears to be a crucial difference in how this concomitance is understood. As we have seen, al-Asháāi (at least as reported by Ibn Fūrak) depicts the breath-spirit as a condition (shart, mușaḥhịh) for life. Al-Juwaynī must have been aware that the existence of an atom can be a condition only for those accidents that inhere in it, but never for the existence of other atoms or of the accidents that inhere in them: a point, as we have already seen, that he stresses in his refutation of the Mutazili doctrine that bodily structure is a condition for the existence of life. ${ }^{194}$ The presence of the atoms of the spirit within the body, therefore, cannot be a

\footnotetext{
${ }^{188}$ However, al-Baghdādī ( $A s m \bar{a}$, f. 205b) notes that Asháāis who maintain that the spirit is a body claim that the dying person can see his spirit departing from him with his eyes.

${ }^{189}$ Al-Fazārī (Sharḥ al-Irshād, ff. 102a-b), who accepts al-Juwaynī's theory of the spirit, argues that the spirit must have life; for various Qur'ānic verses and hadīths indicate that the spirit continues to know and perceive following the death of the body.

${ }^{190}$ Al-Juwaynī, Shāmil, 160-2.

${ }^{191}$ Al-Juwaynī (Ibn al-Amīr), Ikhtiṣār ff. 103a; 238b.

${ }^{192}$ Al-Rāzī, Ușūl, f. 177b.

193 Though having a special "status", the atoms of the spirit are normal atoms. All atoms, according to classical Asháāis, are homogenous (e.g. al-Baghdādī, Ușūl, 52-5). The notion that the spirit is a body unlike sensible bodies is attributed to the metempsychosists (Usül, 53).

${ }^{194}$ See p. 457-8 above. On that the existence of the substratum is a "condition" for the existence of the accidents it receives, see al-Juwaynī, Shāmil, 711-13. Al-Asháāi reportedly (Ibn Fūrak, Mujarrad, 
cause or a condition for any attributes of the atoms of the body, including life. This point, as we shall see shortly, is stated explicitly by al-Juwaynī's students.

So although, with al-Juwaynī, the spirit is promoted to become a special body of atoms embedded in the living composite rather than mere breath, it is, in another respect, demoted in being deprived of any intrinsic vital functions as either a cause or a condition that engenders any property for the composite. The concomitance between the spirit and life becomes based entirely on God's direct preservation of the normal course of events (which al-Juwayni mentions twice in the last citation and also appears in al-Qushayrî's definition). Unlike most other occurrences in the created world, not even a semblance of causality is admitted here. ${ }^{195}$ And al-Juwaynī would agree with al-Baghdādi that it is possible ( $j \vec{a}$ ' iz, mumkin) for God to bestow life on a being that has no spirit, or to instil a spirit in an inanimate thing, although the latter does not occur in the normal course of events. ${ }^{196}$

Al-Juwaynī's conception of the soul is accepted in some extant late-fifth/eleventhand sixth/twelfth-century Asharī sources that were influenced by him, including al-Mutawallī, al-Fazārī, al-Makkī and the young Fakhr al-Dīn al-Rāzī, who support it with an array of scriptural evidence. ${ }^{197}$ This commitment, however, is not shared by his two most important kalām students, to whom we shall now turn.

\section{iii. Al-Ansārì}

Al-Juwaynī's student al-Anșārī objects, first of all, to the notion that the spirit is a body of some sort that either engenders, or is a condition to, the existence of life and other animate properties in the human body. He argues that since the homogeneity (tajānus) of all atoms has already been established, if one atom is a spirit on account of its essence ( $l i-n a f s i-h i)$, then absolutely all atoms must likewise be spirits on account of their essence. An "ensouled" body would then be intrinsically "spiritual" (rüḥānî) and in need of no extra spirit-atoms. However, the human body is not intrinsically spiritual on account of its essence. Therefore, the spirit can "be neither a body nor an atom". ${ }^{198}$ "No body", he further argues, "can affect another body" (lā athar li-jism fī jism). ${ }^{199}$

280-1) maintained that bodies could not affect other bodies. So although a jinn, being a subtle body, can penetrate the human body, it cannot directly affect it, though it may indirectly influence the person's behaviour by whispering (waswasa) to him.

195 Al-Juwaynī's contemporary al-Mutawallī (Mughnī, 57) paraphrases his short section on the spirit, including the emphasis on God's preservation of the normal course of events, but strangely states that "the spirit causes life (al-rūṭ müjib li-l-ḥayāt)". This position is even more untenable, in classical Asharà thought, than treating the spirit as a condition, unless we read "müjib" in a non-technical sense.

${ }^{196}$ Al-Baghdādī, Asmāà, f. 205b; idem., Ușūl, 105.

${ }^{197}$ Al-Fazārī, Sharh al-Irshāè, f. 102a; al-Makkī, Nihāya, ff. 88a-b; al-Rāzī, Ușūl, ff. 178b-180a. Al-Mutawallī (Mughnī, 57) duplicates al-Juwaynī's definition, but uses "combined" (mujtami), rather than "intermingled".

${ }^{198}$ Al-Anșārī, Ghunya, f. 217b; idem., Sharḥ al-Irshād (MS Aya Sofia), f. 268b.

${ }^{199}$ Al-Anșārī, Ghunya, f. 217b. 
Al-Anșārī, therefore, views al-Bāqillānī's identification of the spirit as the accident of life favourably. He describes this thesis as "good" (hasan), but does not go any further to defend or elaborate it. ${ }^{200}$ Instead, he concedes the possibility that the spirit be a body of some sort, but with an important caveat: that it be acknowledged that God maintains the association between the existence of the spirit and the continuation of life simply as "the normal course of events", rather than on account of the former being a "cause" for the latter (ja'ala dhälika 'ädatan lā illatan). ${ }^{201}$ The spirit may be an inanimate body ( $j$ ism jamād) similar to the blood, nourishment and the breath, which neither cause life nor act as conditions for it, but are simply concomitant (lāzama) with it: God normally creates the accident of life in the human body as long as He creates these other bodies, and normally omits to create life in the absence of any one of them. ${ }^{202}$ Though he accepts the conceivability of this, al-Anșārī is non-committal and appears to suspend judgement on whether the spirit is a body or an accident.

\section{iv. Al-Kiyā al-Harrāsī}

Al-Juwaynī's other student al-Harrāsī goes further and does not hesitate to reject his teacher's doctrine that the soul is a subtle body embedded in the dense (kathif) body of man. ${ }^{203}$ He uses the same argument put forth by al-Anșārī: the spirit cannot be a body, "because we have already demonstrated that bodies [i.e. atoms] are homogeneous; so if one body is a spirit, all bodies would be spirits". Moreover, "if it is conceivable for one body to become living by a body that is adjacent to it (jāwara-hu), it would have been possible for Zayd to become living by 'Amr". ${ }^{204}$ The spirit, therefore, is an accident, though al-Harrāsī does not explain whether or not it is identical to life.

It is possible to reconcile this conception of the spirit with hadiths that indicate that the spirits of the believers (al-Harrāsī does not specify martyrs) are in the crops of green birds in heaven or "in lanterns hanging beneath the Throne". For the accident of spirit could inhere in an atom of the individual's body, which is transported to that heavenly realm, while the rest of the body, despite being reduced by an infinitesimal atom, would otherwise remain unchanged. In contrast to al-Bāqillānī, al-Harrāsī does not suggest that the substratum that receives the accident of spirit could be other than the original body in which it inhered.

\section{Conclusion}

As well as being the product of the school's brand of atomism, classical Asháāi anthropology moreover reflects man's ambivalent status in classical kalām as

${ }^{200}$ Al-Anșārī, Sharḥ al-Irshād (MS Aya Sofia), f. 269a.

${ }^{201}$ Al-Anșārī, Sharḥ al-Irshād (MS Aya Sofia), f. 269a.

${ }^{202}$ Al-Anșārī, Sharḥ al-Irshād (MS Aya Sofia), ff. 268b-269a; idem., Ghunya, ff. 217b; $218 \mathrm{a}$.

${ }^{203}$ Al-Harrāsī, Ușūl, f. 248a. Al-Harrāsī's position is reported by Sayf al-Dīn al-Āmidī (Abkār al-afkār, ed. A. M. al-Mahdī, 5 vols. [Cairo: Dār al-Kutub wa-l-Wathā'iq al-Qawmiyya, 2002], 4, 274).

${ }^{204}$ Al-Harrāsī, Ușūl, f. 247b. 
both an epistemic starting point for several major doctrines concerning divine nature and the focus and ultimate object of knowledge in other theological contexts. God and man were investigated and conceptualised within the same ontological framework, and the priority was almost invariably given to the articulation of sound doctrines and arguments about God, even where they entailed rather unattractive doctrines about man, most obviously here the denial of the unity of man for the sake of affirming the unity of God. The result of this kalām theocentrism, as we have seen, is an ontologically fragmentary conception of man, despite the occasional appeal to cardiocentrism, which affords the heart a central cognitive role and renders the other parts of the body subservient to it. This implication, however, did not deter our theologians, who were satisfied that the attributes specific to animate beings, which they postulated, offered a sound explanation for all the occurrences and activities that took place within the human individual.

There was no theoretical need to postulate anything other than the bodily structure and the accidents that inhered in its atoms. Account, however, had to be taken of the numerous references to the "spirit" in the Qur'ān and the Hadīth. Refusing to add another ingredient to the body, some felt that they could reduce the "spirit" to the attribute of life, or explain it away as the mysterious air that flows through the nostrils and mouth in and out of the body. That the names of the spirit (rüh, nafs, nasama) were etymologically related to names of flowing air ( $r i \bar{h}$, nafas, nasim) even suggested that "breath" was a conveniently literal interpretation of "spirit". For others, this conception failed to explain various scriptural depictions of the spirit, and hence posited a subtle body within the human body, which may depart from it, travel in space and experience the posthumous occurrences described in revelation.

As a subtle body, however, the spirit seems only to exacerbate the fragmentary constitution of man: it is distinct from the human body, has no association with either the heart or any of man's animate attributes, and has no function to play in the living being. Its role and status become even more problematic following death, when it departs from the body and begins to have its own experiences in a non-terrestrial realm while parts of the body are subjected, independently of the spirit, to an inquisition and possibly punishment in the grave.

Although the question why, in the late fifth/eleventh century, al-Ghazālì and alRāghib al-Ișfahānī turned away from this theory of man towards a philosophicallyinfluenced body-soul dualism goes well beyond the scope of our present article, we can safely speculate that they must have been mindful of the failings and limitations of classical Asharāi anthropology. To al-Ghazālī, the investigation of human ontology served, first and foremost, not as a starting point for doctrines concerning divine nature nor to define the subject of obligation ( mukallaf), but to articulate a soteriology of ethical and noetic development. In a variety of ways, the Avicennan model proved more conducive to this new anthropocentric and introspective orientation in Ash'arī thought. The spirit ( $r \bar{u} h$, nafs) that, as a subtle body, had a redundant and problematic status was promoted to become a separate and incorporeal rational soul, which became the 
principle for the unity of the individual. Yet the doctrine of the rational soul faced serious opposition in late classical Asharism since it clashed with key school tenets; and it was only assimilated fully by Fakhr al-Dìn al-Rāzi around the turn of the seventh/thirteenth century. This will be the subject of a further study.

\section{Appendix}

\section{A New Source: Al-Fazārī's Sharhh al-Irshād}

MS London, British Library, OR. 9645, of 126 folios of text, contains the last volume of a multi-volume (either three- or four-volume) commentary on al-Juwaynī's Irshād. The portion commented on in this volume is from the beginning of the chapter on prophecy to the end of the book, although some folios are missing at the end (it, hence, corresponds to Irshäd, pp. 302-424). The text is transcribed in a clear Maghribi script; and the margins contain numerous notes and additions, which appear to be in the same hand. The marginalia, unfortunately, are often illegible because of worming and water damage.

The author's name stated in the Latin script on the spine of the codex, bound in the early twentieth century, ${ }^{205}$ is Ibn al-Mar'a, that is, the Andalusian Ibrāhīm ibn Yūsuf (d. 611/1214-15), who indeed is known to have written a four-volume commentary on this work. ${ }^{206}$ Of the original title page, only two small fragments have survived, one bearing a note indicating that the copy is an autograph, "Sharh Irshäd Imām al-Haramayn rahima-bu Allāh bi-khaț al-mușannif". The author's name is not given.

In the main text, however, the author's comments are frequently introduced by, "Alī ibn Muhammad said" (e.g. f. 1a). In some cases, the name is appended with, "may God prevent him from error ('așama-bu)" (f. 20b), "forgive his sin (ghafara . . dhanba-bu)" (f. 22a), "guide him (waffaqa-bu)" (f. 101b), etc., rather humble phrases that confirm that this indeed is an autograph copy. The only Maghribi commentator on the Irsha $d$ with this name is 'Alī ibn Muḥammad al-Fazārī (b. 509/1115; d. Granada, 552/1157 or 557/1162), also known as Ibn al-Nafzī, who reportedly entitled his commentary Manhaj al-sadād, or Minhāj al-sadād fì sharh al-Irshād ${ }^{207}$ This work is one of the earliest extant commentaries on the Irsh $\bar{a} d$; and in the long tradition of commentaries on this work in the Maghrib, it is probably second only to a commentary written by Abū 'Abd Allāh Muhammad ibn Muslim al-Māzarī, who moved to Egypt (d. Alexandria, 530/1136). Al-Fazārī's commen-

${ }^{205}$ According to a note on a flyleaf, the codex was bought from the well-known collector Abraham Shalom Yahuda (1877-1951) on 10 October 1925.

${ }^{206}$ See Peter Stocks, Subject Guide to the Arabic Manuscripts in the British Library, ed. C. Baker (London: British Library, 2001), 97. On Ibn al-Mar’a, see, for instance, Khalīl ibn Aybak al-Ṣafadī, al-Wāfi bi-l-wafayāt, Vol. 6, ed. S. Dedering (Wiesbaden: Franz Steiner, 1972), 171.

${ }^{207}$ On him see, for instance: 'Umar R. Kaḥhāla, Mújam al-mu'allifìn, 7 vols. (Damascus: al-Maktabat al-Arabiyya, 1967-1961), 2, 491; Ibn 'Abd al-Malik al-Marrākushī, al-Dhayl wa-l-takmila, ed. I. 'Abbās, 8 vols. (Beirut: Dār al-Thaqāfa, 1965), 5, 282-5; Ibn Farhūn al-Mālikī, al-Dībāj al-mudhahhabfì ma'rifat a'yān 'ulamā' al-madhhab, ed. M. A. Abū l-Nūr, 2 vols. (Cairo: Dār al-Turāth, 1972), 2, 115-16. Some published sources name him, it appears incorrectly, "Ibn al-Baqarī" or "Ibn al-Muqri", rather than "Ibn al-Nafzī". 
tary, used here for the first time, is a valuable new classical Ashari source, both in that it sheds light on the highly developed state of Maghribi Asharism in the early sixth/twelfth century and in the surprising wealth of material it cites from earlier, non-extant sources that were at the author's disposal, including works by al-Ash 'arī, al-Bāqillānī, al-Juwaynī and Maghribi authors. No other manuscript copies of this work are known to be extant. 